\title{
Winter stream temperature in the rain-on-snow zone of the Pacific Northwest: influences of hillslope runoff and transient snow cover
}

\author{
J. A. Leach $^{1}$ and R. D. Moore ${ }^{1,2}$ \\ ${ }^{1}$ Department of Geography, University of British Columbia, 1984 West Mall, Vancouver, British Columbia, Canada \\ ${ }^{2}$ Department of Forest Resources Management, University of British Columbia, 1984 West Mall, \\ Vancouver, British Columbia, Canada
}

Correspondence to: J. A. Leach (jason.leach@geog.ubc.ca)

Received: 1 October 2013 - Published in Hydrol. Earth Syst. Sci. Discuss.: 31 October 2013

Revised: 20 January 2014 - Accepted: 23 January 2014 - Published: 27 February 2014

\begin{abstract}
Stream temperature dynamics during winter are less well studied than summer thermal regimes, but the winter season thermal regime can be critical for fish growth and development in coastal catchments. The winter thermal regimes of Pacific Northwest headwater streams, which provide vital winter habitat for salmonids and their food sources, may be particularly sensitive to changes in climate because they can remain ice-free throughout the year and are often located in rain-on-snow zones. This study examined winter stream temperature patterns and controls in small headwater catchments within the rain-on-snow zone at the Malcolm Knapp Research Forest, near Vancouver, British Columbia, Canada. Two hypotheses were addressed by this study: (1) winter stream temperatures are primarily controlled by advective fluxes associated with runoff processes and (2) stream temperatures should be depressed during rain-on-snow events, compared to rain-on-bare-ground events, due to the cooling effect of rain passing through the snowpack prior to infiltrating the soil or being delivered to the stream as saturation-excess overland flow. A reach-scale energy budget analysis of two winter seasons revealed that the advective energy input associated with hillslope runoff overwhelms vertical energy exchanges (net radiation, sensible and latent heat fluxes, bed heat conduction, and stream friction) and hyporheic energy fluxes during rain and rainon-snow events. Historical stream temperature data and modelled snowpack dynamics were used to explore the influence of transient snow cover on stream temperature over 13 winters. When snow was not present, daily stream temperature during winter rain events tended to increase with increasing air temperature. However, when snow was present, stream
\end{abstract}

temperature was capped at about $5{ }^{\circ} \mathrm{C}$, regardless of air temperature. The stream energy budget modelling and historical analysis support both of our hypotheses. A key implication is that climatic warming may generate higher winter stream temperatures in the rain-on-snow zone due to both increased rain temperature and reduced cooling effect of snow cover.

\section{Introduction}

Stream temperature influences a variety of biological, chemical and physical in-stream processes, such as dissolved oxygen concentrations and aquatic organism survival and growth rates (Wehrly et al., 2003, 2007; Friberg et al., 2013). Stream temperature is controlled by different energy exchanges, including vertical fluxes at the stream surface (net radiation, sensible and latent heat fluxes), bed heat conduction, advective fluxes (channel-intercepted rainfall, groundwater and tributary inflows, and hyporheic exchange), and heat generated by frictional dissipation of potential energy as water flows downslope. Changes in land cover and climate can alter the relative importance and magnitudes of these energy exchange processes, and there are concerns that corresponding temperature responses could be deleterious to existing aquatic communities (Brown et al., 2007; Durance and Ormerod, 2007, 2009), particularly for cold- and cool-water species such as salmonids (Battin et al., 2007). Process-based understanding of the energy exchanges controlling stream thermal regimes at a range of spatial and temporal scales is needed to effectively manage and predict stream temperature 
response to future land cover and climatic changes (Webb et al., 2008; Arismendi et al., 2012).

Most stream temperature research has been concerned with summer temperatures, particularly in response to riparian forest disturbance such as harvesting or wildfire (e.g. Johnson and Jones, 2000; Bartholow, 2005; Gaffield et al., 2005; Gomi et al., 2006; Gravelle and Link, 2007; Leach and Moore, 2010; Janisch et al., 2012; Imholt et al., 2013). This summer-focused research consistently identifies energy exchanges occurring at the stream surface (primarily net radiation) as a key control on temperature variability on diurnal to seasonal scales and the response to changes in riparian canopy conditions. In some reaches, however, surfacewater-groundwater interactions can significantly moderate temperature variability (e.g. Johnson, 2004; Moore et al., 2005; Leach and Moore, 2011; MacDonald et al., 2014).

In contrast to the depth and breadth of research on summer stream temperature, few studies have examined winter stream temperature processes despite its recognized importance for aquatic ecosystems (Beschta et al., 1987; Holtby, 1988; Ebersole et al., 2006; Brown et al., 2011; Shuter et al., 2012). Salmonids are poikilothermic, so decreases in stream temperature correspond with declines in metabolic processes and the ability of fish to swim, feed, and avoid predators (Brown et al., 2011). Therefore, predation by homeothermic predators during winter is believed to be high, particularly when surface ice cover is non-existent or incomplete (Huusko et al., 2007; Watz et al., 2013). In many temperate regions, particularly the coastal portions of the Pacific Northwest of North America (PNW), headwater catchments experience moderate air temperatures and transient snow cover. As a result, headwater streams in these regions typically remain unfrozen during most of the winter, and their thermal regimes may be particularly sensitive to changes in winter air temperature and precipitation. Under these conditions, even a relatively small (e.g. $1-2{ }^{\circ} \mathrm{C}$ ) but persistent change to stream temperature could have a significant effect on fish bioenergetics and on rates of growth and development of invertebrates that dominate salmonid food sources (Brown et al., 2011; Arismendi et al., 2013).

Winter in coastal portions of the PNW region is characterized by frequent cloud cover and precipitation. Therefore, solar radiation should be a less important control on stream temperature than in summer, especially considering the low solar elevation angles. Although we are unaware of any published wintertime stream energy budgets in the coastal portion of the PNW, studies from sites outside this region have found that magnitudes of energy exchanges occurring at the stream surface are smaller during winter than during summer periods (Webb and Zhang, 1997, 1999; Hannah et al., 2008; Leach and Moore, 2010). An important characteristic of the coastal portion of the PNW is that, at low to medium elevations, frequent rain and rain-on-snow events maintain high flows, which could result in substantial lateral advection of thermal energy via hillslope runoff.
This study addressed two hypotheses: (1) winter stream temperatures in headwater catchments of the rain and rainon-snow zones of the PNW region are primarily controlled by advective fluxes associated with runoff processes during storm events, and (2) stream temperatures should be depressed during rain-on-snow events, compared to rain-onbare-ground events, due to the cooling effect of rain passing through the snowpack prior to infiltrating the soil or being delivered to the stream as saturation-excess overland flow. The hypotheses were addressed using field data collected at headwater catchments within the rain-on-snow zone at the Malcolm Knapp Research Forest, near Vancouver, British Columbia, Canada. A diagnostic energy budget analysis was conducted using data collected during the winters of 2011/2012 and 2012/2013 from a heavily instrumented catchment and supplemented with $13 \mathrm{yr}$ of historical stream temperature data (1997-2002, 2007-2008, and 2010-2013) and modelled snowpack dynamics for an adjacent catchment to explore winter thermal regimes and the role of transient snow cover. The methodology and results of the energy budget study are presented in Sect. 3, followed by the methodology and results of the historical study in Sect. 4. The two complementary studies are discussed together in Sect. 5.

\section{Study area}

Research was conducted at the University of British Columbia's Malcolm Knapp Research Forest, located at $49^{\circ} 16^{\prime} \mathrm{N}$ and $122^{\circ} 34^{\prime} \mathrm{W}$, about $60 \mathrm{~km}$ east of Vancouver (Fig. 1). The area experiences a maritime climate with mild wet winters and warm dry summers. Mean annual precipitation at the University of British Columbia (UBC) Research Forest headquarters ( $147 \mathrm{~m}$ a.s.l.) is $2184 \mathrm{~mm}$, of which $70 \%$ falls, primarily as rain, between October and April due to Pacific frontal systems. Snowfall comprises only $5 \%$ of the total annual precipitation at the low-elevation headquarters station but increases at higher elevations. Streamflow typically responds rapidly to rainfall. Runoff generation processes are dominated by subsurface flow and, to a lesser extent, saturation-excess overland flow (Thompson and Moore, 1996; Hutchinson and Moore, 2000). Forest cover is composed of second-growth western red cedar (Thuja plicata), Douglas-fir (Pseudotsuga menziesii) and western hemlock (Tsuga heterophylla). Soils are primarily coarse-textured humo-ferric podzols (Feller and Kimmins, 1979). Soil depths range up to $2 \mathrm{~m}$, with compacted till or granitic bedrock found on average at $1 \mathrm{~m}$ depth. Granitic bedrock underlies both the till and soil layers, and bedrock outcrops occur along topographic divides. Average hydraulic conductivities are typically $10^{-4}$ to $10^{-3} \mathrm{~m} \mathrm{~s}^{-1}$ in the soil and $10^{-7}$ to $10^{-6} \mathrm{~m} \mathrm{~s}^{-1}$ in the underlying till (Utting, 1979; Cheng, 1988; Hutchinson and Moore, 2000; Haught and van Meerveld, 2011). Owing to the high permeability of the soils, almost all water reaching the ground surface infiltrates the soil and 


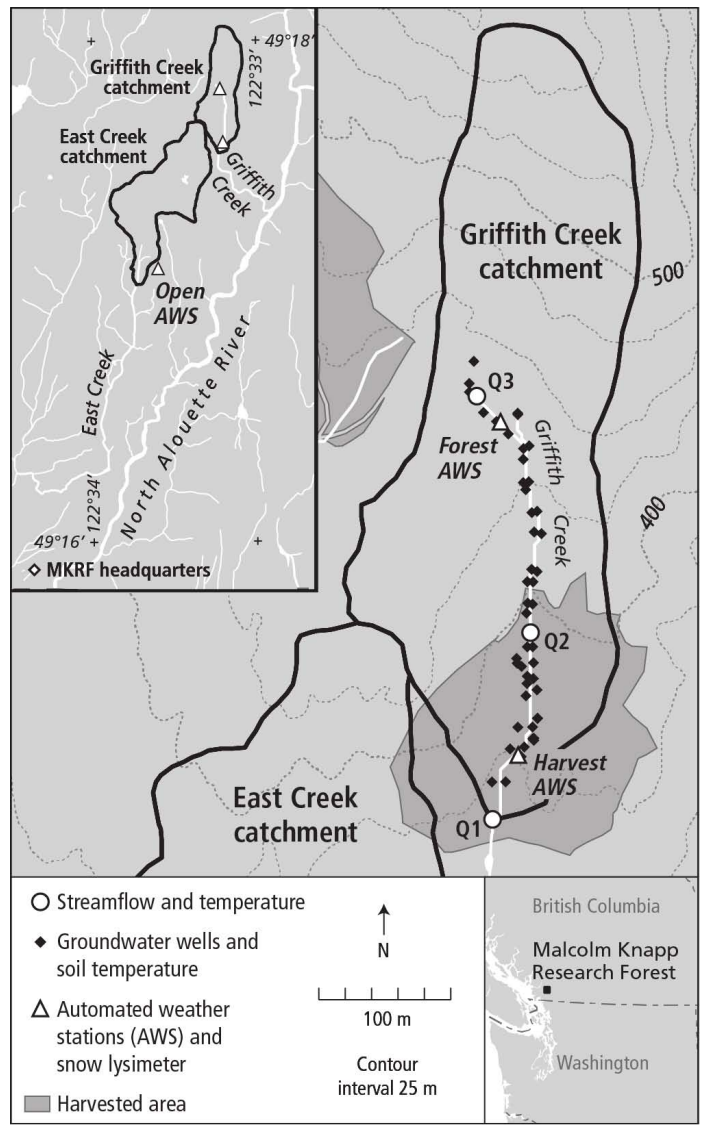

Fig. 1. Map of Griffith Creek and East Creek study catchments.

flows downslope in a saturated layer above the contact between the soil and underlying till or bedrock. Most stormflow occurs in the autumn-winter wet season and many streams dry up during the summer.

Griffith Creek was the focus of the energy budget study. At the location of a hydrometric weir, it drains an area of $11 \mathrm{ha}$, ranging from 365 to $572 \mathrm{~m}$ a.s.l. Temperature data for East Creek were used in the historical analysis. At the location of the temperature logger, East Creek's catchment has an area of 44 ha and ranges in elevation from 280 to $447 \mathrm{~m}$ a.s.l. East Creek's catchment was logged in the 1920s and is currently covered by mature forest stands about $80 \mathrm{yr}$ old, with crown closures of 75-95\%. Griffith Creek's catchment had similar forest cover until autumn of 2004, when the lower section of the catchment was logged under a partial retention approach, resulting in $50 \%$ of the basal area being removed and a $14 \%$ reduction in canopy closure (Guenther et al., 2012). Currently, the lower section's vegetation cover is composed of sparse mature trees and a shrub understory about $1-3 \mathrm{~m}$ in height. The shrub understory experiences considerable dieback during the winter months. The upper portion of Griffith Creek's catchment is covered by mature forest similar to that in East Creek's catchment. For the energy budget analysis the stream was divided into two reaches, which are referred to herein as the "harvest" and "forest" reaches. The harvest reach was bounded by Q1 and Q2 and was $220 \mathrm{~m}$ in length with a slope of $0.09 \mathrm{~mm}^{-1}$ and classified as a steppool morphology; the forest reach was bounded by Q2 and Q3 and was $340 \mathrm{~m}$ in length with a slope of $0.16 \mathrm{~mm}^{-1}$ and classified as step-pool and cascade (Fig. 1). Wetted channel widths varied with discharge but generally averaged $1 \mathrm{~m}$ or less for both reaches. Griffith and East Creek catchments are characterized by high topographic relief, which provide substantial terrain shading. Channels are not heavily incised and shading from channel banks is minimal. East Creek supports a population of coastal cutthroat trout (Oncorhynchus clarki clarki) (De Groot et al., 2007).

\section{Energy budget study at Griffith Creek}

\subsection{Data collection}

Field data were collected at Griffith Creek from October 2011 to May 2013. Field measurements were aimed at quantifying the energy and water balance components for use within a diagnostic energy budget for two stream reaches. Details of these measurements are provided below.

\subsubsection{Precipitation and snowpack}

At a meteorological station located at a recent clearcut, hereinafter referred to as the open site (Fig. 1), a tipping bucket rain gauge was used to measure liquid precipitation, a bulk precipitation gauge measured rain and snowfall, and a snow lysimeter measured snowmelt and rainfall. The bulk precipitation gauge consisted of a $1.2 \mathrm{~m}$ length of PVC pipe ( $20.32 \mathrm{~cm}$ diameter) that was sealed at the bottom and equipped with a pressure transducer. The pipe contained antifreeze to melt snow and was topped with a thin layer of mineral oil to minimize evaporation. The tipping bucket and bulk precipitation gauges were logged by Campbell Scientific CR10x loggers and data were stored every $10 \mathrm{~min}$. The snow lysimeter $\left(4 \mathrm{~m}^{2}\right.$ area and $0.0625 \mathrm{~mm}$ per tip) was constructed following the design by Smith (2011) and was logged with an Em5b data logger (Decagon Devices, Pullman, Washington). Total drainage from the lysimeter (rainfall plus snowmelt) was stored every $1 \mathrm{~h}$.

Two additional snow lysimeters with the same specifications as the open-site lysimeter were installed at Griffith Creek, one in the harvested area and one in the unharvested area. Both sites also had tipping bucket rain gauges installed below the forest canopy, which were used to confirm occurrence of rainfall.

Manual surveys of snow depth and density were made during site visits at the open site, and at the Griffith Creek harvest and forest sites, when a snowpack was present. Snow depth was measured with a ruler at approximately $2 \mathrm{~m}$ intervals along transects at each site that were 80 to $100 \mathrm{~m}$ in length. Snow density was measured using a Federal snow 
sampler. A minimum of five density measurements were made at each site. Snowpack water equivalent was computed as the product of mean depth and mean density, divided by the density of liquid water.

Time-lapse cameras installed at the open site and the Griffith Creek harvest and forest sites captured images daily at 09:00, 12:00 and 15:00 PST (Pacific Standard Time). Images were used to map snow extent and cover and, in conjunction with meteorological data, help identify occurrence of rain-on-snow events (Floyd and Weiler, 2008).

\subsubsection{Streamflow and channel geometry}

Streamflow was monitored at the Griffith Creek catchment outlet (Q1) as well as at two additional locations along the stream reach $(\mathrm{Q} 2$ and $\mathrm{Q} 3)$ (Fig. 1). The drainage areas for Q1, Q2 and Q3 are 10.8, 6.6, and 0.8 ha, respectively. Manual streamflow measurements were made using the constantrate salt dilution injection method (Moore, 2004). Streamflow measurements were accurate to $\pm 5 \%$, based on replicated gauging. The Q1 station had a v-notch weir and pressure transducer, whereas Q2 and Q3 were outfitted with stilling wells and pressure transducers. Rating curves were developed for each location in order to estimate continuous streamflow records.

Average wetted width and depth of the stream were determined from measurements made at 25 locations distributed along Griffith Creek (11 and 14 in the harvest and forest reaches, respectively). Sixteen sets of 25 width and depth surveys were made over a range of stream discharges. Mean width and depth for the lower harvested and upper forested reaches were regressed against discharge in order to fit empirical power-law relations for predicting width and depth for the entire study period. Mean widths ranged between 0.49 and $0.97 \mathrm{~m}$ with a relative standard error of $\pm 21 \%$ for the harvest reach, and 0.28 and $0.62 \mathrm{~m}( \pm 19 \%)$ for the forest reach. Mean depths ranged between 0.10 and $0.27 \mathrm{~m}$ $( \pm 26 \%)$ for the harvest reach, and 0.08 and $0.21 \mathrm{~m}( \pm 37 \%)$ for the forest reach.

\subsubsection{Stream temperature}

Eight submersible temperature loggers (Tidbit v2 Temp, Onset Computer Corporation, accurate to $\pm 0.2^{\circ} \mathrm{C}$ ) were distributed along Griffith Creek. Three of the locations used in this study correspond to streamflow gauging sites Q1, Q2, and Q3. Temperature loggers were installed at sites with sufficient water depth so that loggers were not exposed during low flows. The loggers were shielded with white PVC pipe with drilled holes to facilitate water exchange. Sensors were logged at $15 \mathrm{~min}$ intervals and averaged every $1 \mathrm{~h}$. Sensors were calibrated at 0 and $20^{\circ} \mathrm{C}$ (in an ice bath and at room temperature, respectively), before and after field deployment. Vertical and lateral manual spot measurements were made using a WTW 340i handheld conductivity and temperature meter (accurate to $\pm 0.1^{\circ} \mathrm{C}$ ) at each logger site during site visits to ensure that the logger was placed in a location with full vertical and lateral mixing. Manual spot measurements were also used to check logger records for drift throughout the study.

\subsubsection{Above-stream microclimate}

Two automated weather stations were installed at sites within $2 \mathrm{~m}$ of the Griffith Creek channel to characterize the abovestream microclimate in the forested and harvested reaches. The weather stations monitored air temperature with a HMP45C-L probe (accurate to $\pm 0.3^{\circ} \mathrm{C}$ ), relative humidity with a HMP45C-L probe (accurate to $\pm 3 \%$ for the $0-90 \%$ relative humidity range and $\pm 5 \%$ for the $90-100 \%$ relative humidity range), incoming solar radiation with a CMP3 Kipp and Zonen pyranometer, wind speed with a Met One 3-cup anemometer (starting threshold of $0.45 \mathrm{~m} \mathrm{~s}^{-1}$ ) at approximately $1.5 \mathrm{~m}$ above the ground surface, and rainfall at the ground surface with a tipping bucket rain gauge $(0.254 \mathrm{~mm}$ per tip). All sensors were scanned every $10 \mathrm{~s}$ and averaged (or summed for the rain gauges) every $10 \mathrm{~min}$ by Campbell Scientific CR10x data loggers.

Above-stream net radiation was measured using a roving Kipp and Zonen net radiometer to test predictions from a net radiation model (details provided below). The net radiometer was set up at 14 locations (six and eight locations in the forest and harvest reaches, respectively) along Griffith Creek during the study period in order to sample spatial variability in net radiation due to variable riparian vegetation structure. At each location, the net radiometer was positioned approximately $30-40 \mathrm{~cm}$ above the stream surface. The sensor was scanned every second and readings were averaged every 10 min using a Campbell Scientific CR10x logger.

Radiative exchanges were modelled along the stream surface using hemispherical canopy images and meteorological data, in order to account for spatial variability in riparian canopy structure and surrounding topography (Moore et al., 2005; Leach and Moore, 2010). A Nikon fisheye-converted FC-E8 lens and Nikon Coolpix 45004.0 megapixel digital camera, set on fisheye mode and highest image quality, were used to capture the images. Eighty-two images (34 at the harvest reach and 48 at the forest reach) were taken from the centre of the stream at 5 to $10 \mathrm{~m}$ intervals along the entire study reach. The camera was levelled and oriented to north prior to the images being captured. Images were taken approximately $10-20 \mathrm{~cm}$ above the stream surface. Hemispherical images were also taken at the locations where net radiation was measured and at the two stream meteorological station pyranometers. Images were taken on an overcast day to ensure uniform sky conditions to facilitate image processing. 


\subsubsection{Subsurface water levels and temperature}

Shallow groundwater levels were monitored at 50 wells that were installed by hand augering to the soil-till interface (mean depth was approximately $0.6 \mathrm{~m}$ ). Wells were made from PVC pipe ( $35 \mathrm{~mm}$ inside diameter) with holes drilled along the lower half and screened with permeable garden fabric to prevent soil movement into the well. The wells were located within $5-10 \mathrm{~m}$ of the stream in order to characterize throughflow inputs to the channel. Wells were located to sample a range of hillslope sizes and shapes determined from different topographic indices, including upslope contributing area and topographic wetness index. Forty wells were outfitted with Odyssey capacitance water level loggers (Dataflow Systems Pty Ltd, Christchurch, New Zealand) to provide 15 min-interval water level records. The remaining wells were monitored manually once a week during the winter period. The groundwater well network was surveyed using a total station.

Soil temperatures were recorded within $1 \mathrm{~m}$ of 40 of the groundwater wells. At four sites, soil temperatures were recorded by thermocouples at three depths $(0.05,0.25$ and $0.5 \mathrm{~m}$ ), which were connected to Campbell Scientific CR10x data loggers. Thirty-six of the groundwater well sites were fitted with submersible temperature loggers installed at the soil-till interface using a hand auger and backfilled after installation. Four of these sites had an additional soil temperature logger installed at a second depth above the soil-till interface. In addition, soil temperatures were recorded at two depths $(0.05$ and $0.15 \mathrm{~m})$ at each of the snow lysimeter sites located within the Griffith Creek catchment. All soil temperature sensors logged data at 15 min intervals with the exception of the snow lysimeter sites, where soil temperatures were logged at $60 \mathrm{~min}$ intervals. Temperature loggers were determined to be below or above the water table at each time step based on the known depth of the temperature logger and the corresponding well water level.

Piezometers were installed in the centre of the streambed at 25 locations at approximately even spacing along the study reach. At four step-pool sequences, piezometers were installed upstream of the step and downstream in the pool. Piezometers were constructed from $6 \mathrm{~mm}$-internal-diameter plexiglass tubing with holes drilled in the bottom $5 \mathrm{~cm}$, and were installed to depths of $10-30 \mathrm{~cm}$ below the streambed. Vertical hydraulic gradients were computed as the difference in water level between the inside and outside of the piezometer, divided by the depth of the mid-point of the perforated section (Scordo and Moore, 2009). Positive hydraulic gradients indicate upwelling flow. Water levels inside and outside the piezometers were measured with an electronic beeper and accurate to $\pm 5 \mathrm{~mm}$ (Guenther, 2007). Piezometers were also used to measure saturated hydraulic conductivity of the bed sediments using a falling-head slug test (Freeze and Cherry, 1979). Hydraulic conductivity $\left(K_{\text {sat }}\right)$ was computed based on an equation derived by Hvorslev (1951) and modified by Baxter et al. (2003) for closed-bottom perforated piezometers.

At each of the 25 piezometer locations, thermocouples were installed within the streambed. Twenty-two locations had three thermocouples installed at various depths and three locations had two thermocouples, due to the shallow depth of bed sediment. Thermocouple depths varied by location and ranged between 0.02 and $0.3 \mathrm{~m}$ depending on the ease of installation, which was determined by differences in streambed composition and depth to bedrock. Vertical hydraulic gradients, bed temperatures, and hydraulic conductivity were measured once a month during winter site visits. Based on previous studies reported in the literature and at sites within Malcolm Knapp Research Forest (Moore et al., 2005; Guenther, 2007), we anticipated that bed heat conduction and hyporheic energy fluxes would be secondary terms in the energy budget and therefore devoted more resources to estimating the other fluxes. We performed spot measurements to provide a basis for confirming that these fluxes were indeed secondary terms.

\subsection{Analysis}

A reach-scale energy budget analysis was used to assess the relative importance of the various energy fluxes controlling winter stream temperatures at Griffith Creek. In the following sections we outline the methods used to measure and estimate the various energy exchanges acting on the stream, followed by a description of the reach-scale energy budget equations. Note that the term "surface energy fluxes" is defined as net radiation, and sensible and latent heat fluxes occurring at the stream surface; "vertical energy fluxes" is defined as surface fluxes, bed heat conduction, and stream friction; and "lateral energy fluxes" is defined as advective fluxes from surface runoff and throughflow.

\subsubsection{Net radiation}

Net radiation was modelled using hemispherical images that were analysed with Gap Light Analyser (GLA) software (Frazer et al., 1999) to derive gap fractions as a function of zenith angle and azimuth. The model was evaluated against measured net radiation from the roving net radiometer at Griffith Creek. The net radiation model and approach were identical to that of Leach and Moore (2010), with the exception that an atmospheric pressure of $97 \mathrm{kPa}$ was used. GLA requires a threshold value to be applied to convert hemispherical photos to binary images. An optimum threshold was determined using the hemispherical images associated with the two above-stream pyranometers. Threshold values ranging from 120 to 240 , at 10-unit increments, were used to process the photos, and, for each threshold value, only the incoming solar radiation was modelled. A threshold value of 160 minimized the root mean square error and mean bias error for observed and modelled incoming shortwave radiation 
at the two pyranometer sites. Using the optimized threshold, mean hourly net radiation was modelled and evaluated against measured net radiation at each of the 14 roving net radiometer locations using the associated hemispherical image. For the energy budget, hourly reach-scale mean net radiation $\left(Q_{*}\right.$ in $\mathrm{W} \mathrm{m}^{-2}$ ) was modelled for both the forested and harvested reach using hemispherical images from the respective reaches.

\subsubsection{Latent and sensible heat fluxes}

The latent heat flux $\left(Q_{\mathrm{e}}\right.$ in $\left.\mathrm{W} \mathrm{m}^{-2}\right)$ was computed using an empirical wind function fitted to evaporimeter data collected at Griffith Creek for both pre- and post-harvest conditions (Guenther et al., 2012):

$Q_{\mathrm{e}}=627.8\left[0.0424 \cdot U \cdot\left(e_{\mathrm{a}}-e_{\mathrm{w}}\right)\right]$,

where $U$ is wind speed $\left(\mathrm{m} \mathrm{s}^{-1}\right) ; e_{\mathrm{a}}$ and $e_{\mathrm{w}}$ are the vapour pressures of air and water, respectively $(\mathrm{kPa})$; and $627.8 \mathrm{ac}-$ counts for the unit conversion from $\mathrm{mm} \mathrm{h}^{-1}$ to $\mathrm{W} \mathrm{m}^{-2}$. Saturation vapour pressure ( $e_{\text {sat }}$ in $\mathrm{kPa}$ ) was calculated as a function of air or water temperature, $T_{\mathrm{a}}$ or $T_{\mathrm{w}}\left({ }^{\circ} \mathrm{C}\right)$, using the following relation:

$e_{\mathrm{sat}}(T)=0.611 \cdot \exp \left[\frac{a T}{T+b}\right]$

where $T$ is in ${ }^{\circ} \mathrm{C}$, and the coefficients $a$ and $b$ are given by ( $a$, $b)=(17.27,237.26)$ for $T>0{ }^{\circ} \mathrm{C}$ and $(a, b)=(21.87,265.5)$ for $T \leq 0^{\circ} \mathrm{C}$. The vapour pressure at the water surface, $e_{\mathrm{w}}$, was assumed to equal $e_{\mathrm{sat}}\left(T_{\mathrm{w}}\right)$, while the actual vapour pressure of the air $\left(e_{\mathrm{a}}\right)$ was calculated as

$e_{\mathrm{a}}=\left(\frac{\mathrm{RH}}{100}\right) e_{\mathrm{sat}}\left(T_{\mathrm{a}}\right)$,

where $\mathrm{RH}$ is the relative humidity measured at the nearest stream microclimate station.

The sensible heat flux $\left(Q_{\mathrm{h}}\right)$ was estimated as

$Q_{\mathrm{h}}=\beta \cdot Q_{\mathrm{e}}$

where $\beta$ is the Bowen ratio, calculated as

$\beta=0.66 \cdot(P / 1000) \cdot\left[\left(T_{\mathrm{w}}-T_{\mathrm{a}}\right) /\left(e_{\mathrm{w}}-e_{\mathrm{a}}\right)\right]$,

where $P$ is ambient air pressure, which was assigned the value for a standard atmosphere for the site elevation $(97 \mathrm{kPa})$.

\subsubsection{Bed heat conduction and hyporheic energy exchange}

Spot estimates of bed heat conduction, $Q_{\mathrm{c}}$, were calculated as

$Q_{\mathrm{c}}=K_{\mathrm{c}} \cdot\left(T_{\mathrm{b}}-T_{\mathrm{w}}\right) / 0.05$, where $K_{\mathrm{c}}$ is the thermal conductivity of the streambed material $\left(\mathrm{W} \mathrm{m}^{-1} \mathrm{~K}^{-1}\right)$, and $T_{\mathrm{b}}$ and $T_{\mathrm{w}}$ are bed temperature at depth of $0.05 \mathrm{~m}$ and stream temperature, respectively. The thermal conductivity was assumed to equal $2.6 \mathrm{~W} \mathrm{~m}^{-1} \mathrm{~K}^{-1}$ based on estimates of Lapham (1989) using a porosity of 0.30 , which is typical for gravels (Freeze and Cherry, 1979).

The heat flux associated with hyporheic exchange, $Q_{\text {hyp }}$, for the combined forest and harvest reaches was estimated as

$Q_{\text {hyp }}=\rho c_{p} F_{\text {hyp }}\left(T_{\text {hyp }}-T_{\mathrm{w}}\right) / W$,

where $\rho$ is the density of water $\left(1000 \mathrm{~kg} \mathrm{~m}^{-3}\right) ; c_{p}$ is the specific heat of water $\left(4180 \mathrm{~J} \mathrm{~kg}^{-1} \mathrm{~K}^{-1}\right) ; F_{\text {hyp }}$ is hyporheic exchange rate per unit length of channel $\left(\mathrm{m}^{3} \mathrm{~s}^{-1} \mathrm{~m}^{-1}\right) ; T_{\text {hyp }}$ and $T_{\mathrm{w}}$ are the temperatures of upwelling hyporheic water and stream water, respectively; and $W$ is the mean stream width (m). The mean of streambed temperatures from upwelling sites was used for $T_{\text {hyp }}$. $Q_{\text {hyp }}$ was not calculated separately for the forest and harvest reaches because of the limited number of piezometer and streambed temperature sites available to compute $F_{\text {hyp }}$ and $T_{\text {hyp }}$.

A reach-scale estimate of $F_{\text {hyp }}$ was computed by assuming that all water infiltrating the bed within the reach follows subsurface flow paths that discharge within the same reach. It was further assumed that the fraction of the total bed area that experiences downwelling is equal to the fraction of the piezometers with downwelling flow. Following from these assumptions, $F_{\text {hyp }}$ was computed as

$F_{\text {hyp }}=\left(n_{\text {dw }} / n_{\text {piezo }}\right) \cdot A \cdot q_{z} / L$,

where $n_{\mathrm{dw}}$ and $n_{\text {piezo }}$ are the number of piezometers indicating downwelling flow and the total number of piezometers, respectively; $A$ is the area $\left(\mathrm{m}^{2}\right)$ of the streambed; $q_{z}$ is the vertical flux of water infiltrating the streambed $\left(\mathrm{m} \mathrm{s}^{-1}\right)$; and $L$ is the reach length (m). The area of the streambed was computed as the product of reach length and mean surface width, which was computed from the fitted relation with discharge.

Infiltration rates were estimated based on Darcy's Law:

$q_{z}=K_{\mathrm{sat}} \cdot|\Delta h / \Delta z|$

where $K_{\text {sat }}$ is the saturated hydraulic conductivity of the bed $\left(\mathrm{m} \mathrm{s}^{-1}\right)$, determined from slug tests, and $\Delta h / \Delta z$ is the mean vertical hydraulic gradient from piezometers that registered downwelling flow.

\subsubsection{Stream friction}

Heat generated by fluid friction as water flows downstream, $Q_{\mathrm{f}}\left(\mathrm{W} \mathrm{m}^{-2}\right)$, was computed as

$Q_{\mathrm{f}}=\rho \cdot g \cdot Q \cdot S / W$, 
where $g$ is the gravitational acceleration $\left(9.81 \mathrm{~m} \mathrm{~s}^{-2}\right) ; Q$ is the reach-average discharge $\left(\mathrm{m}^{3} \mathrm{~s}^{-1}\right)$, which is assumed to be equal to the mean of the upstream and downstream discharges; $S$ is the slope of the reach $\left(\mathrm{mm}^{-1}\right)$ extracted from a $5 \mathrm{~m}$ resolution digital elevation model of the catchment; and $W$ is the average wetted width of the stream reach (m).

\subsubsection{Lateral heat fluxes calculated as residual of stream energy budget}

Energy budget analyses were conducted for the 2011/2012 and 2012/2013 winter periods (1 October to 1 May) for the harvest reach and the forest reach. The longitudinal heat transfer $\left(J_{i}\right)$ was calculated at 10 min time steps at each gauging site as

$J_{i}=\rho \cdot c_{p} \cdot Q_{i} \cdot T_{i}$,

where $Q_{i}$ is the discharge $\left(\mathrm{m}^{3} \mathrm{~s}^{-1}\right)$, and $T_{i}$ is the stream temperature, at gauging site $i$.

The difference between $J_{i+1}$ and $J_{i}$ is equal to the sum of the net heat input to the reach and change in heat storage within the reach. This energy budget formulation does not require knowledge of travel times. The storage term was found to be negligible and is not included in the calculation of lateral advective heat flux, described below. The energy exchanges at the stream surface (net radiation, sensible, and latent heat) and stream friction were estimated using the modelling approach described above and were subtracted from the net heat input to the reach. The residual was attributed to the lateral advective heat input $\left(J_{\mathrm{adv}}\right)$ :

$J_{\mathrm{adv}}=J_{i+1}-J_{i}-L \cdot W \cdot\left(Q_{*}+Q_{\mathrm{h}}+Q_{\mathrm{e}}+Q_{\mathrm{f}}\right)$,

where $L$ is the length of the stream reach (m); $W$ is the average wetted width of the stream reach (m); and $Q_{*}, Q_{\mathrm{h}}$, $Q_{\mathrm{e}}$, and $Q_{\mathrm{f}}$ are the fluxes of net radiation, sensible heat, latent heat, and heat inputs due to stream friction $\left(\mathrm{W} \mathrm{m}^{-2}\right)$, respectively.

\subsubsection{Effective lateral inflow temperature}

The effective lateral inflow temperature $\left(T_{\text {adv }}\right)$ was calculated as

$T_{\mathrm{adv}}=J_{\mathrm{adv}} /\left[\left(Q_{i+1}-Q_{i}\right) \cdot \rho \cdot c_{p}\right]$.

The calculated value of $T_{\text {adv }}$ was compared to the 40 measurements of near-stream soil temperature. To explore how $T_{\text {adv }}$ responded to different hydroclimatic event types, daily means of $T_{\text {adv }}$ were calculated and each day during the study was classified as (1) rain on ground, (2) rain on snow, (3) no precipitation and bare ground, or (4) no precipitation and snow cover.

\subsubsection{Error analysis}

A standard approach for error analysis (Bevington and Robinson, 2003) was applied to the stream energy budget
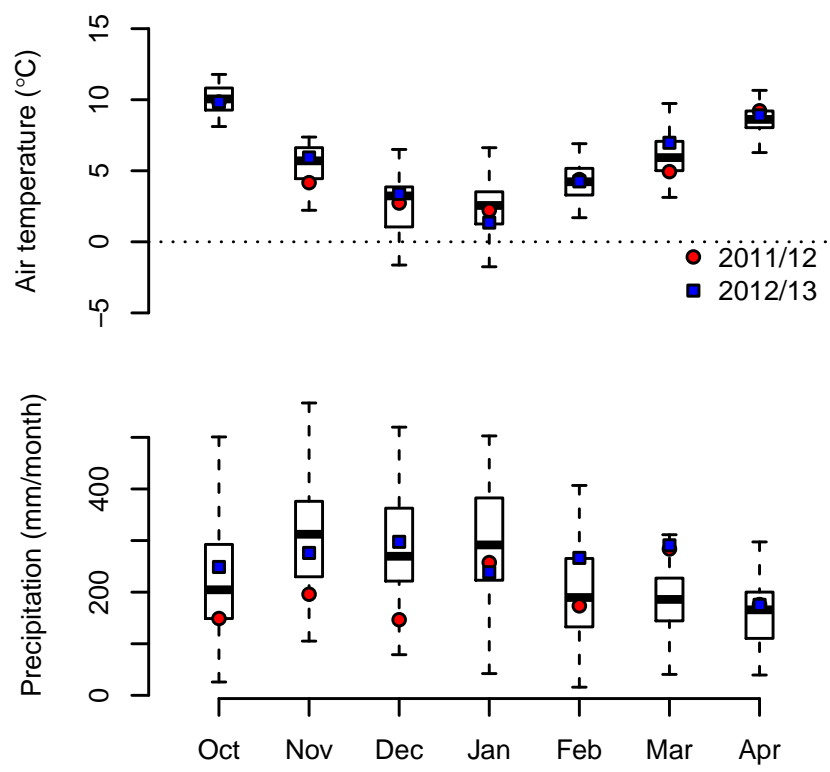

Fig. 2. Boxplots of monthly (October to April) mean air temperature and monthly total precipitation recorded at the MKRF headquarters station from 1962 to 2010 . Red circles and blue squares represent conditions during the two winter periods (2011/2012 and $2012 / 2013$, respectively) during which the detailed field study at Griffith Creek was conducted.

calculations in order to assess uncertainty. The propagated probable error was determined using the following values: $Q_{*} \pm 22 \mathrm{~W} \mathrm{~m}^{-2}, Q_{\mathrm{e}} \pm 25 \%, Q_{\mathrm{h}} \pm 25 \%, Q \pm 5 \%$, $T_{\mathrm{w}} \pm 0.2{ }^{\circ} \mathrm{C}, L \pm 10 \%, S \pm 20 \%, W \pm 21 \%$ (harvest reach) and $\pm 19 \%$ (forest reach). The values for $Q_{*}, Q, W$, and $T_{\mathrm{w}}$ were determined from uncertainty assessments of field measurements, whereas the remaining errors were deemed to be reasonable estimates that erred in the direction of overestimation.

\subsection{Results}

\subsubsection{Overview of study period}

Figure 2 places the 2011/2012 and 2012/2013 field seasons within a broader climatic context using long-term (1962 to 2013) climate data from the MKRF headquarters station. Monthly mean air temperatures for October to April for the two field seasons were generally within the middle $50 \%$ of historic values. There was more variability in precipitation patterns, as October through December of 2011/2012 was dry relative to historic conditions, whereas precipitation during the 2012/2013 season was generally similar to or well above the long-term median.

Griffith Creek was a net gaining stream during the study. The net gain in streamflow was greater for the forest reach (Q3 to Q2) than for the harvest reach (Q2 to Q1), consistent with the differences in drainage area (Fig. 3). The 2012/2013 winter experienced higher peak flows than 2011/2012 and 

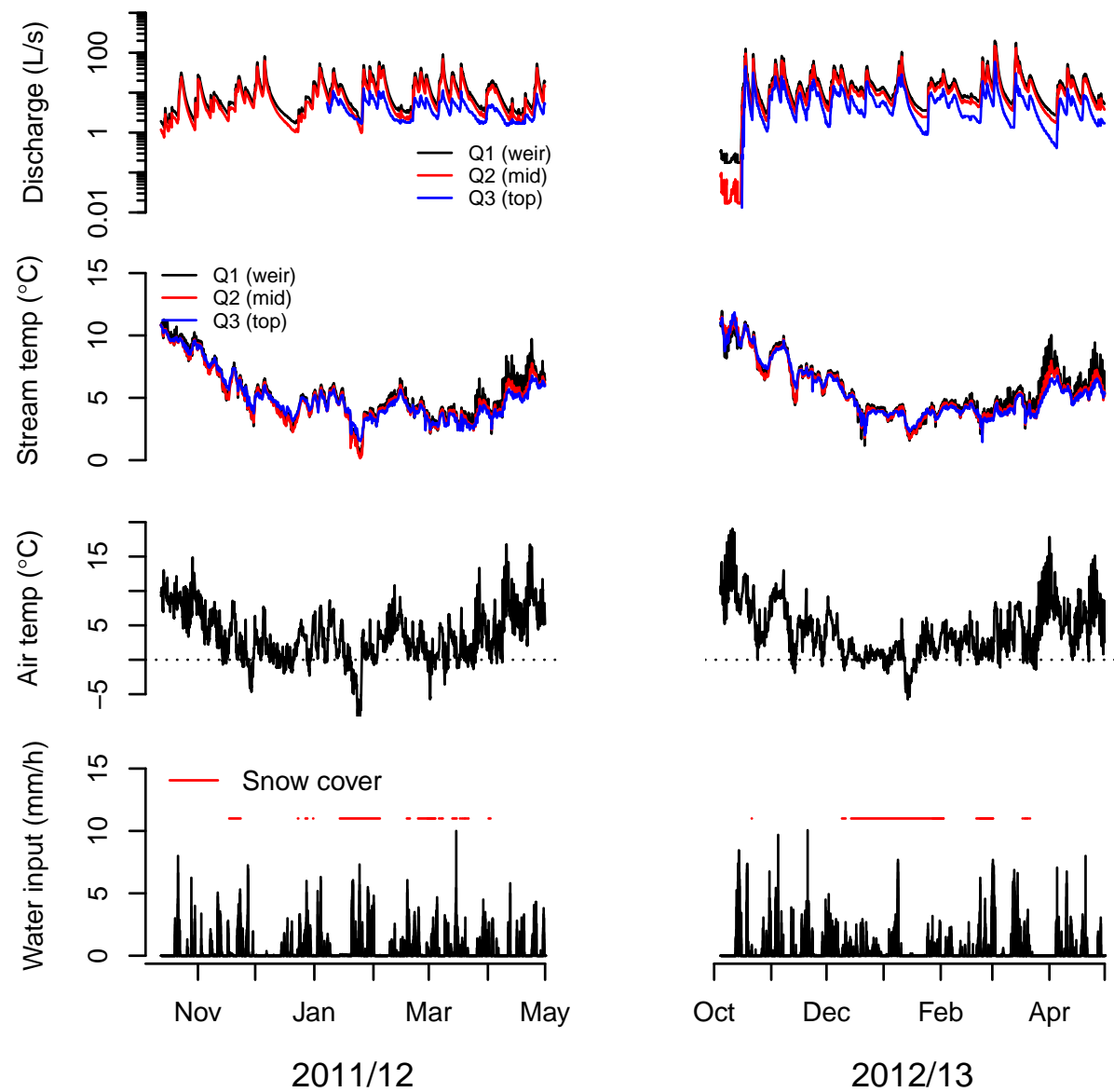

Fig. 3. Hydroclimatic overview for the 2011/2012 and 2012/2013 winter periods (October to May). Water input refers to rainfall and snowmelt measured by the snow lysimeter located at the open site.

discharge was generally more responsive to rain events in 2012/2013, particularly for the Q3 site. This difference in discharge response between the two years was similar for other headwater catchments in the research forest (data not shown).

Mean hourly stream temperatures varied between 1 and $12{ }^{\circ} \mathrm{C}$ during the study period (Fig. 3). Mean hourly longitudinal stream temperature differences between Q1, Q2, and Q3 were often less than $0.5^{\circ} \mathrm{C}$. However, in April, temperatures at $\mathrm{Q} 1$ tended to be about $1^{\circ} \mathrm{C}$ greater than at Q2 and Q3 during the day. Maximum diurnal range in hourly temperatures at Q1 were 3.2 and $3.4{ }^{\circ} \mathrm{C}$ for $2011 / 2012$ and $2012 / 2013$, respectively. Mean diurnal range in hourly temperatures was $0.9^{\circ} \mathrm{C}$ for both winters. Stream temperature did not have a consistently positive or negative relation with discharge, but seemed to vary with discharge depending on the antecedent air and stream temperatures. Mean hourly air temperatures fell below $0^{\circ} \mathrm{C}$ for only short periods (less than one week) during winter.

Total water input (rainfall plus snowmelt) measured at the open-site lysimeter for the study periods (1 October to 1 May) was $1736 \mathrm{~mm}$ for $2011 / 2012$ and $1950 \mathrm{~mm}$ for
2012/2013. The 2011/2012 winter had 52 days of snow cover in the forested area and 63 days in the harvested area, spread over a number of events, whereas the 2012/2013 winter had 71 days of snow cover in both forested and harvested areas, mostly due to a snowpack that persisted from 14 December to 25 January.

\subsubsection{Energy balance}

Hourly modelled net radiation was compared to measured net radiation at the 14 net radiometer locations during the study period. The root mean square error and mean bias error ranged between 17 and 22, and -18 and $-6 \mathrm{~W} \mathrm{~m}^{-2}$, respectively, across the 14 sites. These errors are similar to those found in previous efforts to model above-stream net radiation from hemispherical photographs (Leach and Moore, 2010; Bulliner and Hubbart, 2013).

Streambed hydraulic conductivity based on multiple slug tests across sites had a mean of $4.2 \times 10^{-5} \mathrm{~m} \mathrm{~s}^{-1}$ and vertical hydraulic gradients ranged between -0.6 and $0.5 \mathrm{~cm} \mathrm{~cm}^{-1}$. Guenther et al. (2014) measured similar downward gradients during summer, but their upward gradients were generally 
Table 1. Summary of discharge $(Q)$, number of piezometers indicating downwelling flow $\left(n_{\mathrm{dw}}\right)$, total number of piezometers measured $\left(n_{\text {total }}\right)$, reach-average vertical hydraulic gradient for $n_{\mathrm{dw}}\left(\mathrm{VGH}_{\mathrm{dw}}\right)$, mean temperature difference between $T_{\text {hyp }}-T_{\mathrm{w}}$ for upwelling sites, and estimated reach average $Q_{\text {hyp }}$. Note $T_{\text {hyp }}$ was not measured for the first three dates.

\begin{tabular}{lrccccc}
\hline Date & $\begin{array}{r}Q \\
\left(\mathrm{~L} \mathrm{~s}^{-1}\right)\end{array}$ & $n_{\mathrm{dw}}$ & $n_{\text {total }}$ & $\begin{array}{c}\mathrm{VGH}_{\mathrm{dw}} \\
\left(\mathrm{cm} \mathrm{cm}^{-1}\right)\end{array}$ & $\begin{array}{c}\text { Mean } T_{\mathrm{hyp}}-T_{\mathrm{w}} \\
\left({ }^{\circ} \mathrm{C}\right)\end{array}$ & $\begin{array}{c}Q_{\mathrm{hyp}} \\
\left(\mathrm{W} \mathrm{m}^{-2}\right)\end{array}$ \\
\hline 30 November 2011 & 10.4 & 19 & 25 & -0.26 & NA & NA \\
6 December 2011 & 3.5 & 15 & 24 & -0.18 & NA & NA \\
1 February 2012 & 38.1 & 13 & 25 & -0.36 & NA & NA \\
9 November 2012 & 7.1 & 18 & 25 & -0.56 & 0.6 & 40.4 \\
10 January 2013 & 24.2 & 13 & 25 & -0.36 & 0.3 & 9.4 \\
3 March 2013 & 34.5 & 13 & 25 & -0.37 & 0.2 & 6.4 \\
\hline
\end{tabular}

weaker than our winter measurements. Table 1 shows the number of piezometers with downwelling flow, total number of piezometers sampled, vertical hydraulic gradients calculated for piezometers with downwelling flow, reach-average differences between $T_{\text {hyp }}$ and $T_{\mathrm{w}}$ for the upwelling locations, and $Q_{\text {hyp }}$ estimates for six dates when all piezometer sites were sampled. For flows below about $10 \mathrm{Ls}^{-1}$, up to almost $80 \%$ of the piezometers registered downwelling flow, with the fraction dropping to just over $50 \%$ at higher flows. Temperature differences between $T_{\text {hyp }}$ and $T_{\mathrm{w}}$ were less than $0.7^{\circ} \mathrm{C}$ and estimates of the reach-average heat transfer associated with hyporheic exchange were less than $50 \mathrm{~W} \mathrm{~m}^{-2}$. Both the fraction of piezometers registering downwelling flow and the difference in hyporheic and stream temperatures decreased with increasing discharge, suggesting that the energy transfer associated with hyporheic exchange also declines with increasing discharge. Although we did not determine separate values of $Q_{\text {hyp }}$ for the forest and harvest reaches due to the small number of samples, the limited data suggest that there was not a substantial difference between the reaches in terms of $T_{\text {hyp }}$ and percentage of piezometers with downwelling flow. For bed heat conduction calculations, temperature gradients between the stream and bed were small during all spot measurements and across all locations. Temperature differences between the stream and bed at depths of $15 \mathrm{~cm}$ were less than $0.8^{\circ} \mathrm{C}$ and often less than $0.2^{\circ} \mathrm{C}$. Estimates of bed heat conduction were less than $15 \mathrm{~W} \mathrm{~m}^{-2}$.

Figure 4 shows estimated hourly surface energy fluxes and the heat inputs due to stream friction for the harvest and forest reaches for 2011/2012 and 2012/2013. Net radiation was the dominant surface energy flux. Hourly net radiation ranged between -70 and $150 \mathrm{~W} \mathrm{~m}^{-2}$ for the harvest reach and -60 and $120 \mathrm{~W} \mathrm{~m}^{-2}$ for the forest reach, whereas the sensible and latent heat exchanges at both reaches never exceeded $\pm 30 \mathrm{~W} \mathrm{~m}^{-2}$. During the months of November to February for both $2011 / 2012$ and 2012/2013, net radiation was mostly an energy loss from the stream. Starting in late February, net radiation was an energy source to the stream during day and a sink during night. Heat generated by frictional dissipation of potential energy averaged between 15 and $30 \mathrm{~W} \mathrm{~m}^{-2}$ over the study periods and ranged between 0.2 and $219 \mathrm{~W} \mathrm{~m}^{-2}$ for the harvest reach and 4.8 and $218 \mathrm{~W} \mathrm{~m}^{-2}$ for the forest reach. Heat inputs due to friction were greatest during high flows.

Figure 4 summarizes the reach-scale energy budget analysis for the 2011/2012 and 2012/2013 winter periods at the harvest and forest reaches. Except during low-flow periods, when lateral inputs of water became relatively small, the vertical energy exchanges were only a small fraction of the total heat input into either the harvest or forest reaches even accounting for uncertainty in the flux estimates. Figure 5 illustrates that, for discharges above approximately $25 \mathrm{~L} \mathrm{~s}^{-1}$, surface energy fluxes account for less than $2 \%$ of the heat input to the reach. For discharges below $25 \mathrm{~L} \mathrm{~s}^{-1}$, surface energy fluxes can account for a considerable proportion of the net reach heat input, both as a heat source and sink, as indicated by positive or negative ratios, respectively, in Fig. 5. Most of the highly negative ratios correspond with periods of large relative errors in the heat budget calculations, particularly due to the small changes in discharges along the reach. Surface fluxes were, on average, 4.6 and $4.5 \%$ of the net heat input to the forest reach during the 2011/2012 and 2012/2013 winter periods, respectively, and slightly greater at 9.3 and $5.9 \%$ during 2011/2012 and 2012/2013, respectively, for the harvest reach. However, during some low-flow periods, when advective inputs and heat generated by friction were minimal, the surface fluxes accounted for nearly the entire change in longitudinal heat flux along the reaches. The pattern of net heat input into the reaches followed that of discharge, which highlights lateral advection as a dominant heat input to the stream reach. The generally higher magnitude of net heat inputs for 2012/2013 vs. 2011/2012 reflects the higher magnitude of streamflow that year. Relative magnitudes of the surface energy inputs between the forest and harvest reaches were similar between the two years.

\subsubsection{Effective lateral inflow temperature}

Figure 6 shows the observed near-stream subsurface temperatures ( $n=33$ sites for $2011 / 2012$ and $n=40$ for $2012 / 2013$ ) 


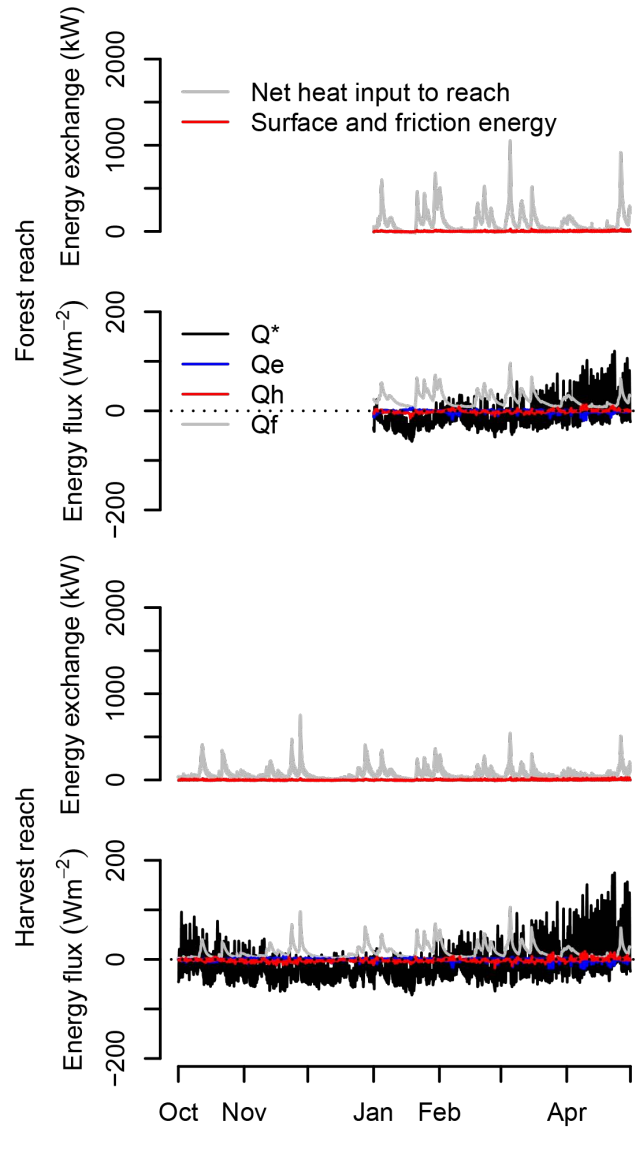

$2011 / 12$
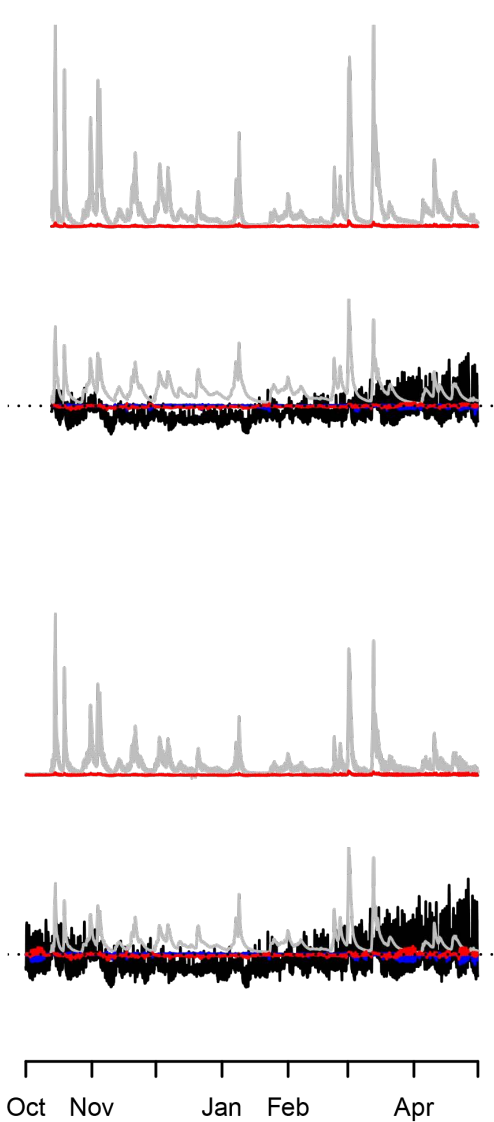

2012/13

Fig. 4. Time series of hourly energy budget components (net radiation, $Q_{*}$; latent heat flux, $Q_{\mathrm{e}}$; sensible heat flux, $Q_{\mathrm{h}}$; and heat addition due to friction, $Q_{\mathrm{f}}$ ) for the forest and harvest reaches for 2011/2012 and 2012/2013. Note the difference in units and scales of the plots comparing net heat input to the reach with surface and friction energy exchanges, and the plots showing the energy fluxes of net radiation, sensible heat, latent heat, and friction.

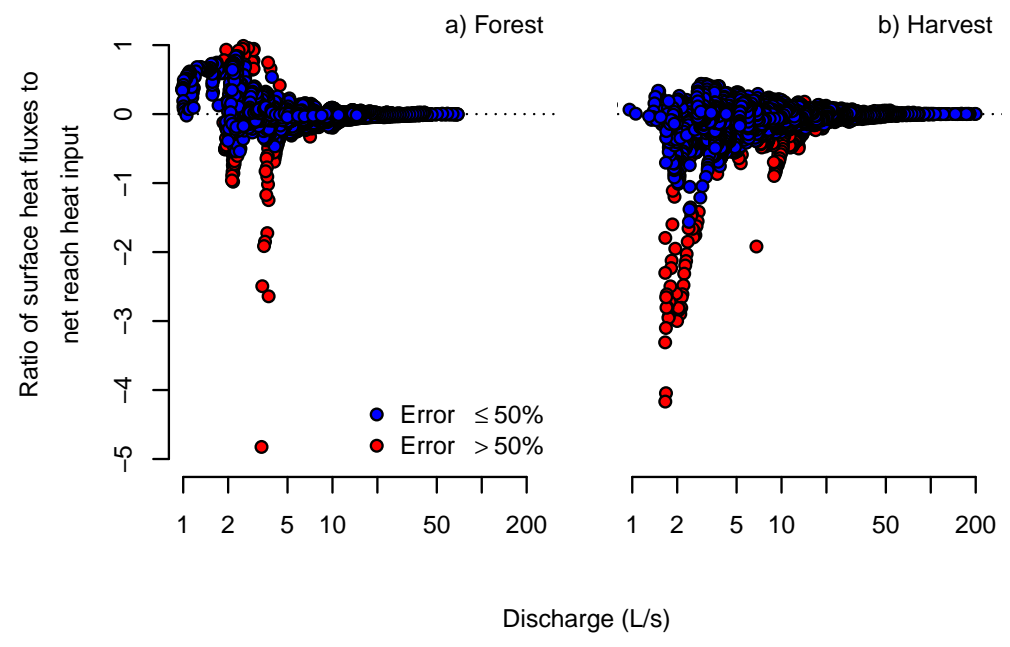

Fig. 5. Ratios of the surface energy fluxes to the net heat inputs for the forest and harvest reaches plotted against hourly discharge at the lower boundary of the respective reaches. Red circles indicate ratios with relative errors less than or equal to $50 \%$, and blue circles indicate ratios with relative errors greater than 50\%. Plots include both 2011/2012 and 2012/2013 data. Positive ratios indicate that the surface fluxes are adding heat to the reach and negative ratios indicate they are removing heat from the reach. Note the $x$ axis scale is logarithmic. 

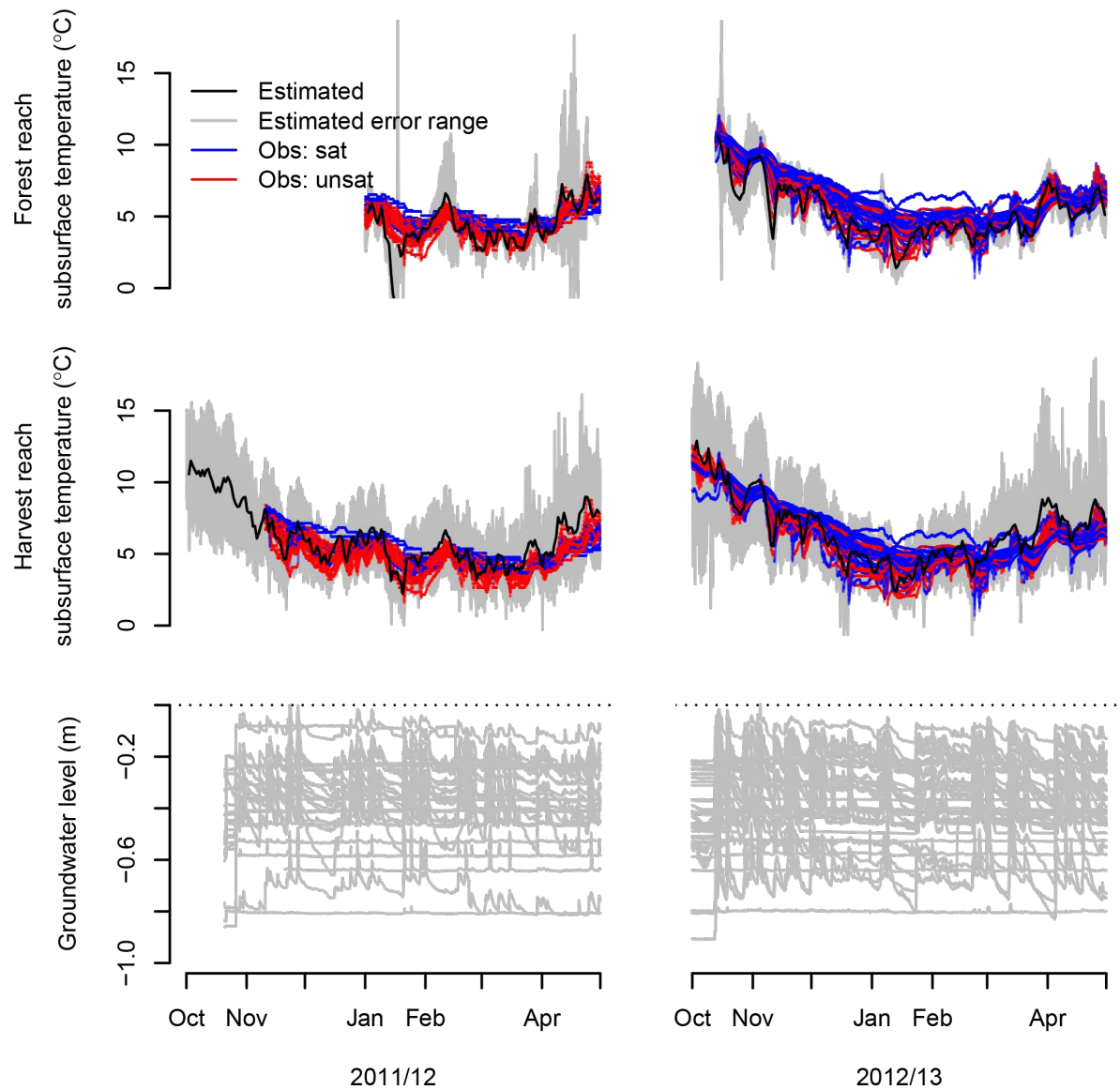

Fig. 6. Comparison of back-calculated effective advective temperature and observed near-stream subsurface temperatures, as well as groundwater table observations for the 2011/2012 and 2012/2013 winter periods. The black lines are the calculated effective advective temperature and the grey bands represent the probable error range. During periods where the subsurface temperature logger is below the water table the observed temperature line is blue, and it is red for periods when the logger is above the water table.

and the probable range of back-calculated effective lateral inflow temperatures (taking into account the propagated uncertainties), as well as hourly groundwater table levels. The water table levels exhibited a flashy response to storm events. The observed subsurface temperatures are temporally variable, differ spatially by up to $5^{\circ} \mathrm{C}$ and plot within the probable range of effective lateral inflow temperatures. The few periods when observed subsurface and estimated lateral inflow temperatures do not agree (e.g. forest reach in midJanuary 2012) correspond to periods of low streamflow when water and heat contributions from the hillslope would be relatively small and vertical heat exchanges would be more important. The effective lateral inflow temperature has a wider uncertainty range for the harvest reach compared to the forest reach because of smaller differences in upstream and downstream discharge, which produces higher relative uncertainty in the estimates of net water input to the reach.

Figure 7 shows daily mean effective lateral inflow temperatures and daily mean air temperatures for both winter periods classified for four event types: (1) rain on ground,
(2) no precipitation and bare ground, (3) no precipitation and snow cover, and (4) rain on snow. The scatter plots illustrate that, for air temperatures in the range of $0-5^{\circ} \mathrm{C}$, lateral inflow temperatures during rain-on-snow events are dominantly below $5^{\circ} \mathrm{C}$ in the forest reach and $6^{\circ} \mathrm{C}$ in the harvest reach, whereas they commonly range up to $8^{\circ} \mathrm{C}$ for rain-on-ground events in both reaches. Observed subsurface temperatures for loggers that were below the water table showed a similar relationship to air temperature when classified into the four event types (data not shown).

\section{Historical study at East Creek}

The relationship between hydrometeorologic event type and winter stream temperature at East Creek was examined using $13 \mathrm{yr}$ of stream temperature data. The historical study complements the energy budget study by addressing the role of snow cover on stream temperature during rain events by extending the limited period of study of the detailed energy budget analysis and sampling more precipitation events over 


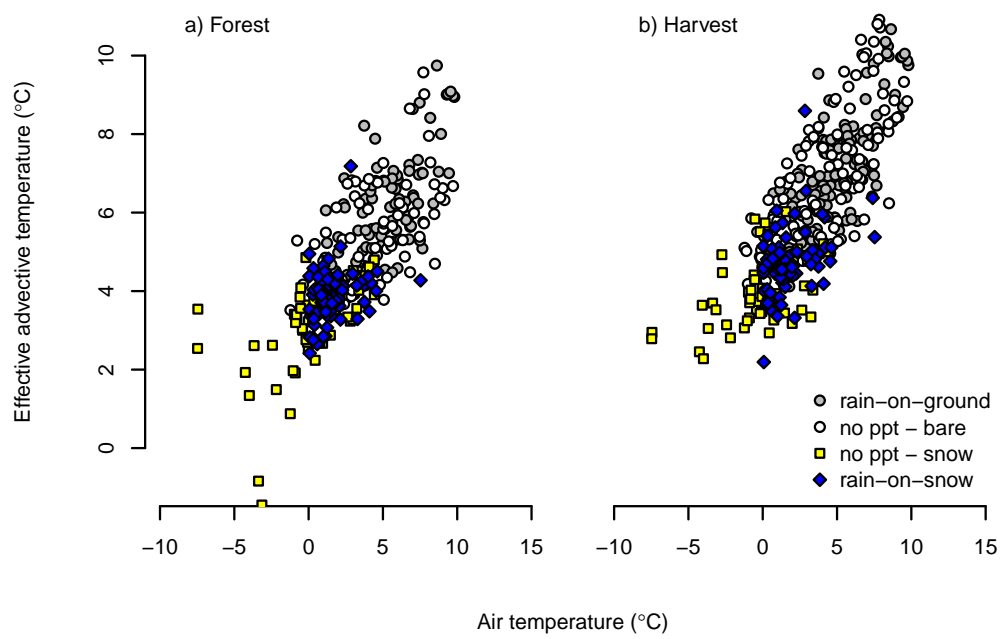

Fig. 7. Calculated mean daily effective advective temperature for four event types for the forest and harvest reaches during winter $2011 / 2012$ and 2012/2013.

variable snow and weather conditions. The following sections outline the data collected as well as details of a snow accumulation and melt model used to simulate historic snow cover at East Creek. The model output was used, in conjunction with air temperature and precipitation data, to classify days into five categories: (1) rain on ground, (2) bare ground and no precipitation, (3) snowing, (4) snow on ground and no precipitation, and (5) rain on snow.

\subsection{Data sources}

Continuous stream temperature measurements were made at the East Creek catchment outlet from 1997 to 2002, 2007 to 2008 , and 2010 to 2013, using submersible Onset Tidbit temperature loggers (accurate to $\pm 0.2^{\circ} \mathrm{C}$ ). The loggers were programmed to record and store temperature readings every $20 \mathrm{~min}$. Loggers were fitted with radiation shields made from white PVC pipe with holes drilled through the pipe to facilitate water exchange. Sensors were calibrated at 0 and $20^{\circ} \mathrm{C}$ (in an ice bath and at room temperature, respectively) before and after field deployment. Daily mean winter (November to March) stream temperatures were calculated from the continuous records. Daily air temperature, rainfall, snowfall, and presence/absence of snow were recorded at the Research Forest headquarters weather station. In addition, a time-lapse camera was installed near the East Creek outlet from 2011 to 2013 and was used to determine presence of snow cover in the catchment.

\subsection{Modelling snow cover at East Creek}

Due to the elevation difference between the headquarters climate station and East Creek, as well as data gaps in the snow record at the headquarters climate station, a simple temperature-based snow accumulation and melt model was used to simulate snow cover at East Creek. We chose a temperature-based snow model for two reasons. First, it has a minimal number of model parameters that need to be calibrated compared to more physically based models. Second, East Creek has dense canopy cover resulting in little solar radiation reaching the ground surface and also low wind speeds; therefore, snowmelt is primarily driven by longwave radiation from the forest canopy, which is strongly related to air temperature (Black et al., 1991; Pomeroy et al., 2009). For simplicity, the model did not account for cold content and changes in water content. These omissions should not be critical at this site because transient snowpacks are typically wet, isothermal, and shallow. Furthermore, we are primarily interested in predicting the presence/absence of snow on the ground, and not the precise timing of snowmelt runoff.

The snow model was used to estimate snow cover at East Creek from 1962 to 2013. An elevation of $352 \mathrm{~m}$ was used in the model, which represents the mean elevation of the catchment. A threshold temperature (TT) was used to partition precipitation into rain (temperature $>\mathrm{TT}$ ) and snow (temperature $<\mathrm{TT}$ ). For precipitation falling as snow, accumulated snow water equivalent (SWE) (mm) was calculated as

$\mathrm{SWE}_{t}=\mathrm{SWE}_{t-1}+\mathrm{SF}_{t}$,

where SF is the amount of snowfall ( $\mathrm{mm}$ ) and $t$ is the day.

For days when the lapsed air temperature was greater than the threshold temperature and snow was present, snowmelt (SM, mm) was calculated as

$\mathrm{SM}_{t}=K_{\mathrm{f}} \cdot T_{t}$,

where $K_{\mathrm{f}}$ is the snowmelt factor $\left(\mathrm{mm}^{\circ} \mathrm{C}^{-1}\right)$ and $T$ is the air temperature $\left({ }^{\circ} \mathrm{C}\right)$. The resulting SWE $(\mathrm{mm})$ was calculated as

$\mathrm{SWE}_{t}=\mathrm{SWE}_{t-1}-\mathrm{SM}_{t}$ 


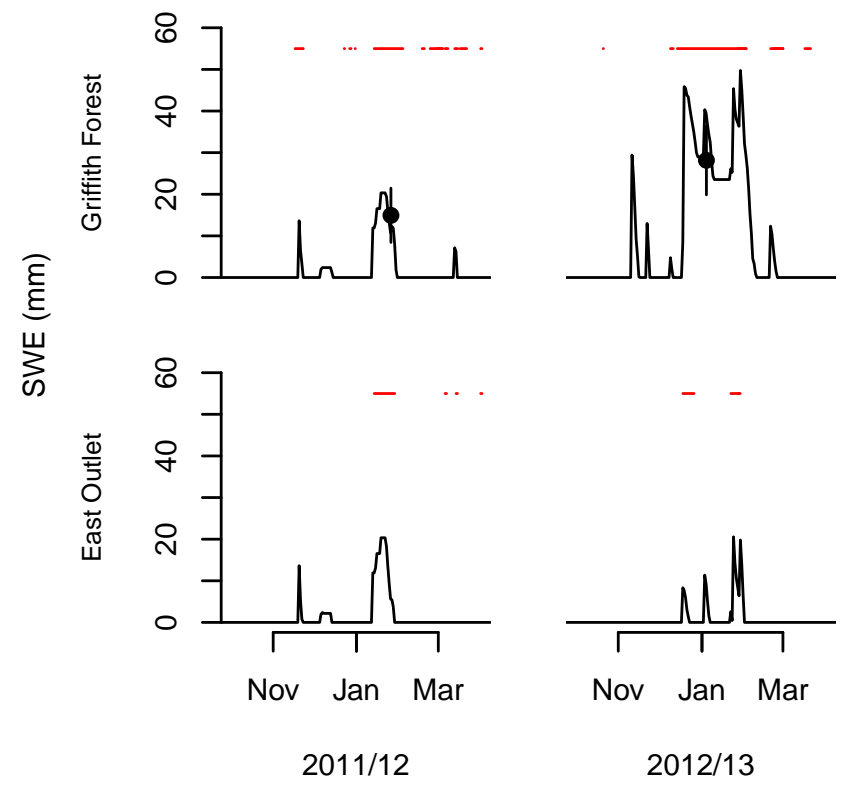

Fig. 8. Comparison of modelled and observed snow cover, and measured snow water equivalence from the forested area of Griffith Creek (430 m elevation), and modelled SWE and observed snow cover at the East Creek outlet (291 m elevation), from October to April for 2011/2012 and 2012/2013. Red horizontal lines indicate periods of snow cover determined from the time-lapse cameras. The black points are mean snow water equivalent (with standard error) from manual snow surveys conducted at the forested site at Griffith Creek.

The snow model used elevation-adjusted air temperature and precipitation from the Research Forest headquarters climate station. The temperature lapse rate was assumed to be $0.006{ }^{\circ} \mathrm{C} \mathrm{m}^{-1}$ (Oke, 1987) and precipitation was assumed to be 1.16 times the precipitation measured at the Research Forest headquarters station based on field measurements made by Hetherington (1976) and Donnelly-Makowecki and Moore (1999).

Values for TT and $K_{\mathrm{f}}$ were calibrated by comparing modelled SWE with manual snow surveys made in the forested region of Griffith Creek ( $430 \mathrm{~m}$ elevation) and also by comparing predicted snow presence with records of snow cover determined from time-lapse photography at the East Creek weir $\left(291 \mathrm{~m}\right.$ elevation). The comparison resulted in $\mathrm{TT}=0^{\circ} \mathrm{C}$ and $K_{\mathrm{f}}=1.5$, which are similar to values determined for forest sites in the southern Coast Mountains of British Columbia in other modelling studies (e.g. Moore, 1993). Running the model using these calibrated values for the elevation of the Research Forest headquarters produced modelled snowfall that generally matched the timing of snowfall recorded at that station.

Figure 8 shows modelled SWE for 2011 to 2013, observed periods of snow cover, and mean snowpack water equivalent with standard errors for two snow surveys, for both the forested portion of Griffith Creek and the area near the East

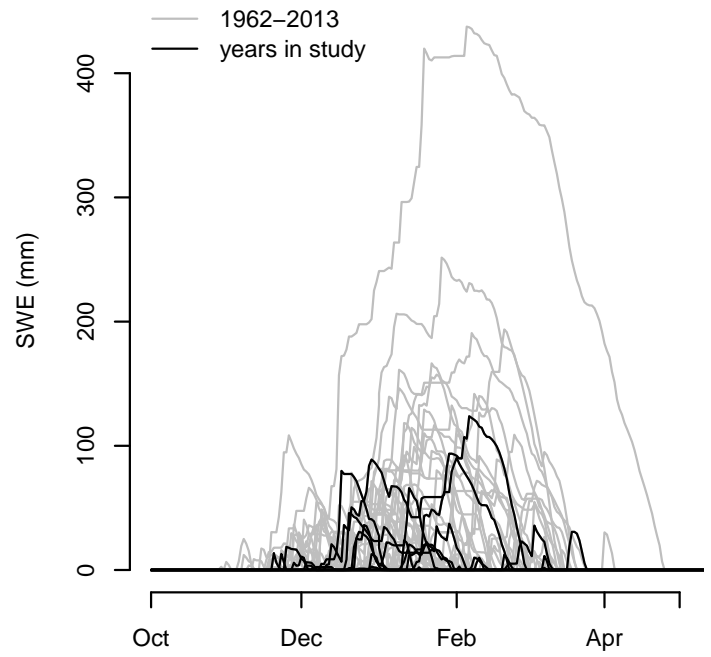

Fig. 9. Comparison of modelled historic snow water equivalent for winters of 1962 to 2013. Black lines represent years used in the historic East Creek study and grey lines represent years for which stream temperature data are not available.

Creek outlet. At both elevations (430 and $291 \mathrm{~m}$ ), the snow model captures the magnitude and duration of the larger, more persistent snowpacks, but tends not to capture the shortduration $(<1$ day) snowpacks.

Figure 9 shows modelled SWE for 1962 to 2013. The years used in this study cover a range of snow accumulation and melt patterns, but generally represent low to moderate accumulations compared to the longer reference period.

\subsection{Stream temperature response to hydroclimatic event type}

For the historic winter records (each winter spanning 1 November to 30 March), 562 days were classified as days with bare ground and no precipitation, 1230 as days with rain on bare ground, 159 as snowing, 228 as no precipitation but snow on the ground, and 241 as rain-on-snow events. Figure 10 shows the relation between daily winter stream temperatures and daily winter air temperatures. On days when a rain-on-snow event occurred, stream temperatures remained below approximately $5{ }^{\circ} \mathrm{C}$, regardless of the corresponding air temperature. In comparison, for the same air temperature range during which rain-on-snow events occurred, stream temperatures were as high as $8^{\circ} \mathrm{C}$ when no snowpack was present in the catchment.

Figure 11 shows daily winter stream temperature as a function of event type for periods when mean daily air temperature was between 0 and $5^{\circ} \mathrm{C}$. This figure highlights that, for similar mean daily air temperatures, mean daily stream temperatures are generally lower when snow is present in the catchment compared to days when snow is absent. Analysis of variance shows that daily mean stream temperatures during rain-on-snow events are about $1.4{ }^{\circ} \mathrm{C}$ lower than during 


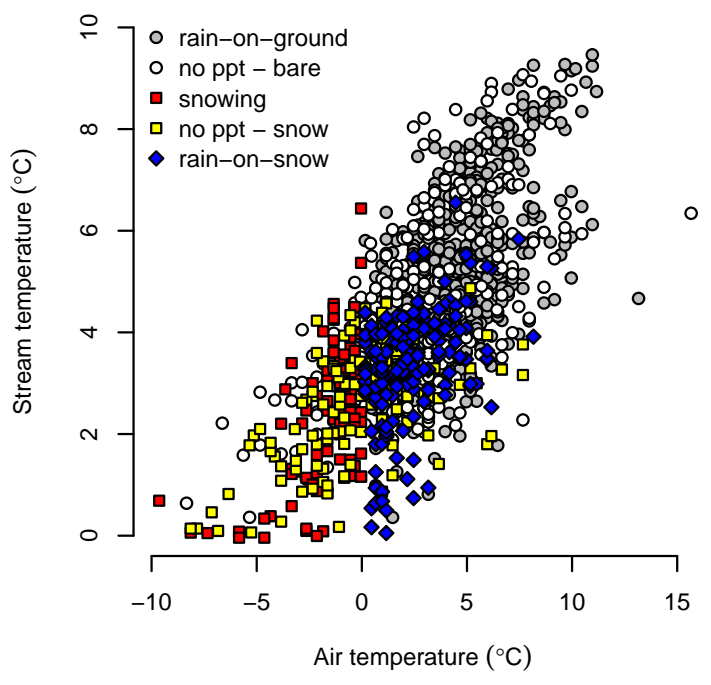

Fig. 10. Daily mean stream temperature at East Creek as a function of air temperature, classified into five event types: (1) rain on bare ground, (2) no precipitation with bare ground, (3) snowing, (4) no precipitation with snow cover, and (5) rain on snow.

rain-on-ground events $\left(3.2\right.$ vs. $\left.4.6^{\circ} \mathrm{C}, p<0.001\right)$. However, the residuals of the analysis of variance exhibit autocorrelation (lag-one autocorrelation coefficient $=0.81$ ), which means that the significance levels may be overstated.

In order to address the issue of autocorrelation, we conducted a Monte Carlo test of significance (further details are provided in Appendix A) to test the null hypothesis that, for air temperatures between 0 and $5^{\circ} \mathrm{C}$, there is no difference in mean stream temperature for rain-on-snow and rain-on-bareground events. We simulated 5000 time series of snow cover using a transition probability matrix and compared the difference in mean daily stream temperature for rain-on-snow and rain-on-bare-ground events for each realization. The observed mean difference of $-1.4{ }^{\circ} \mathrm{C}$ fell outside the range of differences based on 5000 realizations, suggesting a $p$ value of $<0.001$, which is consistent with the ANOVA results.

\section{Discussion}

\subsection{Relative roles of vertical and lateral heat fluxes}

Surface heat fluxes estimated for winter at Griffith Creek were of similar magnitude to those estimated for other studies conducted during winter periods (Webb and Zhang, 1997, 1999; Hannah et al., 2004; Hannah et al., 2008). Net radiation was generally greater in magnitude than the sensible and latent heat fluxes, but was typically less than $100 \mathrm{~W} \mathrm{~m}^{-2}$, representing a heat loss through most of the winter and switching to a heat source in February. The magnitude of the ratio of surface heat fluxes and stream friction to the total heat input to the reach decreased with discharge and became negligible for discharges greater than about $25 \mathrm{~L} \mathrm{~s}^{-1}$.

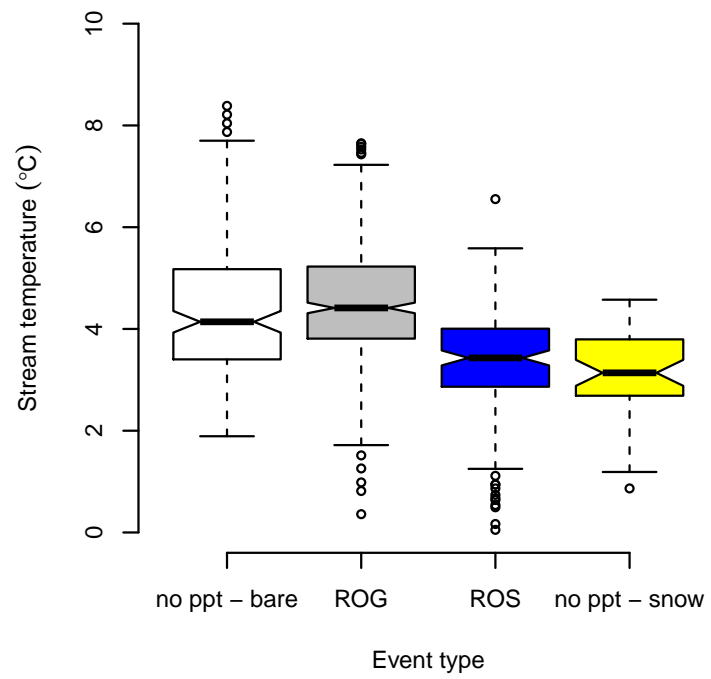

Fig. 11. Boxplots of mean daily stream temperature at East Creek during periods of mean daily air temperature between 0 and $5{ }^{\circ} \mathrm{C}$ for four different event types: (1) no precipitation with bare ground, (2) rain on bare ground (ROG), (3) rain on snow (ROS), and (4) no precipitation with snow cover.

Spot estimates of bed heat conduction were less than $15 \mathrm{~W} \mathrm{~m}^{-2}$ and are similar in magnitude and general direction as found in previous studies that have estimated this term for winter periods (Webb and Zhang, 1999; Hannah et al., 2008). However, Webb and Zhang (1999) did find that bed heat conduction was a large energy sink during the day (as large as $-170 \mathrm{~W} \mathrm{~m}^{-2}$ over an averaging period of $10 \mathrm{~min}$ ), which was related to diurnal patterns in stream temperature. Griffith Creek did not exhibit strong diurnal warming, and, therefore, energy exchanges of the magnitudes estimated by Webb and Zhang (1999) likely did not occur.

Although previous studies have quantified the energy flux associated with hyporheic exchange across the streambed during summer (Story et al., 2003; Moore et al., 2005; Hester et al., 2009; Neilson et al., 2009), no previous studies have estimated this flux for winter periods. Our spot estimates of reach-average hyporheic energy exchange suggest that the magnitude of this term could be up to around $50 \mathrm{~W} \mathrm{~m}^{-2}$ for lower flows, which makes it comparable in magnitude to net radiation. Moore et al. (2005) estimated the hyporheic exchange flux to be up to about $120 \mathrm{~W} \mathrm{~m}^{-2}$ in absolute value at A Creek in the Malcolm Knapp Research Forest. However, that estimate was for low flows on a clear summer day within a clearcut, which would promote a greater contrast in temperature between the hyporheic zone and stream water, and thus a greater hyporheic exchange flux. Guenther (2007) estimated reach-average heat fluxes associated with hyporheic exchange during summer both before and after harvesting at Griffith Creek. Under pre-harvest conditions, $Q_{\text {hyp }}$ was a heat sink during the day and ranged down to about $-20 \mathrm{~W} \mathrm{~m}^{-2}$. Following harvesting, the greater contrast 
in temperature between the hyporheic zone and the stream resulted in $Q_{\text {hyp }}$ down to about $-100 \mathrm{~W} \mathrm{~m}^{-2}$. Considering these summertime estimates and our limited sampling under winter conditions, it appears reasonable to conclude that hyporheic exchange and bed heat conduction are of similar magnitude to the surface energy exchanges during winter and thus could be important heat fluxes at lower flows, but are negligible at higher flows, despite some recent research that shows that transient storage can be an important process during high-flow periods (Ward et al., 2013). Observed temperatures differences between the stream water and bed were often less than $0.3^{\circ} \mathrm{C}$, which limits the magnitude of the hyporheic energy flux, despite uncertainties in the hyporheic water flux. Further research is required to clarify the role of hyporheic heat exchange and its influence on stream temperature dynamics.

Heat generation due to friction is often not included in stream energy budget calculations (Johnson, 2004; Hebert et al., 2011; Benyahya et al., 2012) or is found to be negligible for summer low-flow periods (Webb and Zhang, 1999; Moore et al., 2005). Winter energy budget studies from the United Kingdom report maximum heat inputs due to friction during winter to be less than $4 \mathrm{~W} \mathrm{~m}^{-2}$ for reaches with slopes of 0.0008 and $0.0028 \mathrm{~mm}^{-1}$ (Webb and Zhang, 1999) and up to $60 \mathrm{~W} \mathrm{~m}^{-2}$ for a reach with a slope of $0.01 \mathrm{~mm}^{-1}$ (Hannah et al., 2004). Heat generated due to friction for our relatively steep reaches (slopes of 0.09 and $0.16 \mathrm{~mm}^{-1}$ for the harvest and forest reach, respectively) contributed on average $15-30 \mathrm{~W} \mathrm{~m}^{-2}$ but ranged up to $200 \mathrm{~W} \mathrm{~m}^{-2}$ during high-flow events. Therefore, heat addition due to friction is of the same magnitude as the surface energy fluxes, but is small compared to the lateral advective flux at higher flows.

The reach-scale energy budget analysis highlights that advective fluxes associated with runoff processes dominate the winter thermal regime for coastal headwater catchments except during recession periods between rain and rain-on-snow events. This result is contrary to a number of previous studies that found that, although stream surface energy exchanges are relatively small in magnitude during winter compared to summer, they remained the primary control on stream temperature dynamics (Webb and Zhang, 1997, 1999; Hannah et al., 2008). However, those studies were conducted at point scales or over short reaches (less than $40 \mathrm{~m}$ length) and did not focus on the role of advective fluxes associated with runoff contributions in a headwater context. The potential importance of advective fluxes for winter stream temperature has been recognized in previous studies (Webb and Zhang, 1999; Malard et al., 2001; Leach, 2008; Danehy et al., 2010); however, our study provides the first energy budget analysis to quantify its importance under winter conditions in a headwater catchment. Our findings provide process-based support for recent empirical research suggesting that winter and summer periods of the PNW are characterized by distinct thermal regimes and sensitivities to environmental change (Arismendi et al., 2013).
The significance of lateral advective heat inputs implies that accurate simulation of runoff generation and the temperature of lateral inflow is required to model stream temperature dynamics in regions with frequent winter rain and rain-on-snow events. Most stream temperature models have either ignored lateral advection (e.g. Sinokrot and Stefan, 1993) or assumed a spatially uniform subsurface temperature that is a function of seasonal or annual mean air temperature (e.g. St-Hilaire et al., 2000; Ficklin et al., 2012). Our field observations revealed considerable variability in subsurface temperatures both through time and among loggers. Thirtysix of 40 subsurface temperature sites had a single logger which was installed at the soil-till interface, where lateral flow generation in this system is initiated (Hutchinson and Moore, 2000). However, analysis of the subsurface temperatures at sites with temperature records at multiple depths (not shown here) suggests that, during wet periods when the water table is elevated, vertical temperature differences within the subsurface are less than $0.3^{\circ} \mathrm{C}$. Ongoing research is focused on analysing and modelling the spatial variability of subsurface temperatures, particularly to address the hypothesis that it is a function of hillslope flow paths and thus potentially predictable from hillslope topography (e.g. Jencso et al., 2009). This research would not only have important implications for further understanding and predicting stream temperature dynamics, but would enhance our ability to use temperature as a tracer for understanding hillslope runoff processes (Shanley and Peters, 1988; Kobayashi et al., 1999; Subehi et al., 2010; Birkinshaw and Webb, 2010).

An important question for further research is how the influence of lateral advection changes as one moves down the channel network, especially because larger streams provide habitat for a broader range of aquatic species. As drainage area and stream order increase, streams generally become wider, providing a greater surface area for energy exchange, and the relative change in discharge per unit channel length should decrease. These considerations suggest that lateral advection might become less important as catchment scale increases. In addition, temperature signals at downstream locations would be complicated by the merging of tributaries with varying elevation distributions in their catchment areas. Further field research and modelling effort are required to understand the scale dependence of winter stream temperature dynamics in coastal catchments.

\subsection{Role of transient snow cover and rain-on-snow events}

To our knowledge, no previous research has examined stream temperature response to rain-on-snow events with the exception of Langan et al. (2001), who attributed long-term increases in winter maximum daily temperatures of $2{ }^{\circ} \mathrm{C}$ over $30 \mathrm{yr}$ at a Scottish catchment to reductions in snow cover. Our findings from both Griffith and East creeks indicate that stream temperatures are depressed during rain-on-snow 
events, compared to rain-on-ground events, by about $1-2{ }^{\circ} \mathrm{C}$ for a given air temperature. The magnitude of this temperature depression appeared to be relatively consistent among years, between the forest and logged sites at Griffith Creek, and between Griffith and East creeks. We hypothesize that this temperature depression is due to the cooling of rain as it percolates through the snowpack prior to infiltrating the soil or being delivered to the stream as saturation-excess overland flow.

Our inferences regarding the historic influence of transient snow cover at East Creek depend on the accuracy of the snow model for classifying event types. The snow model appears to capture the larger snow events, which will have the most pronounced impact on the thermal regime, but appears to miss the short-duration (less than a day) and shallow snowpacks that form sporadically during the winter at these sites. One particular source of error is that the model did not account for canopy effects, which would cause a tendency for the model to overestimate snow accumulation, particularly during snow events that contain periods with temperatures slightly above the freezing point, during which intercepted snow tends to melt and reach the ground as canopy drip (Berris and Harr, 1987; Storck et al., 2002). The net effect of model errors would be to classify days with snow cover as days without snow cover, and vice versa, which would act to reduce the apparent stream temperature difference between event types rather than introduce a spurious effect. Classification of days into different event types is also a source of uncertainty, since precipitation can shift phases during a day. However, these phase shifts usually occur over short periods and the longer event dynamics are likely captured by the modelling approach used here. Indeed, the fact that a clear and consistent signal emerged from the analyses over multiple sites and years supports the robustness of the results, despite the presence of some misclassification of event types.

\subsection{Implications of climate and land cover changes}

Given that climate change projections indicate increased winter air temperatures in the Pacific Northwest (Mote and Salathe, 2010) and thus a decrease in transient snow cover, at least at lower elevations, the implication of this study is that climate warming should generate higher winter stream temperatures due to both the increased rain temperature and the reduced cooling effect of snow cover. Persistently higher winter stream temperatures could have a profound effect on the rate of growth and development of salmonid embryos (e.g. Holtby, 1988) and on the rate and timing of invertebrate emergence. Earlier invertebrate emergence could have implications for riparian predators, such as birds, who depend on this food source (Baxter et al., 2005; Richardson et al., 2005). Studies that have examined harvesting-induced winter stream temperature increases suggest that higher winter stream temperatures may promote salmonid growth; however, growth is also highly dependent on food availability (Holtby, 1988;
Leach et al., 2012). Whereas harvesting-induced stream temperature increases are associated with increased solar radiation reaching the stream due to forest canopy removal, stream warming in the context of this study would be driven by warming due to advective fluxes without an increase in solar radiation. This difference may be important since increases in solar radiation reaching the stream due to harvesting could generate increases in primary production, with subsequent food web linkages to invertebrates and salmonids, which may not occur under warming generated by alterations in the advective fluxes (warmer rain and decreased snow cover).

There is less certainty in predicted precipitation changes due to climate change than for air temperature changes; however, the general prediction is an increase in autumn and winter precipitation for the PNW (Rodenhuis et al., 2007; Mote and Salathe, 2010). An increase in precipitation over the winter months would likely result in lateral advective fluxes associated with runoff being an even more dominant control on stream temperature, compared to vertical energy fluxes, than documented here. However, the frequency of precipitation events may have more control than magnitude of precipitation events on the relative importance of the lateral advective fluxes. More frequent precipitation events will sustain runoff to the stream for longer periods of time, thereby reducing the importance of vertical energy exchanges on stream temperature. In contrast, high-magnitude, but less frequent, precipitation events may result in longer periods of between-event low flows and increased importance of vertical energy exchanges.

Land cover changes due to forest harvesting can have a considerable impact on snow accumulation and melt in rainon-snow zones (Berris and Harr, 1987; Marks et al., 1998; Jones, 2000; Hudson, 2001). There were differences in snow accumulation and melt timing between the forested and harvested areas of Griffith Creek; however, these differences were modest (52 vs. 63 days of snow for the forest and harvest sites in 2011/2012, respectively, and 71 days of snow for both forest and harvest sites in 2012/2013 although there were some differences in timing), likely a result of the partial retention harvest treatment, which reduced canopy closure from about $95 \%$ pre-harvest to $80 \%$ post-harvest. It is beyond the scope of this study to examine those differences in snow dynamics, although they are inherently included in the event classification in Fig. 7. Our findings suggest that snow and runoff responses to forest harvesting could have greater impacts on winter stream temperature than surface energy exchange responses to riparian forest removal. Our study found that surface energy fluxes are relatively minor stream temperature controls, except during recession periods, and were relatively insensitive to riparian canopy structure, as indicated by only slight differences in energy fluxes between forest and harvest reaches. In addition, previous studies from our study region found relatively small winter stream temperature responses to forest harvesting, compared to responses in spring and summer (Gomi et al., 2006; Guenther et al., 2014). Management activities focused on riparian vegetation, 
such as buffer strips (Gomi et al., 2006) or afforestation (Webb and Crisp, 2006), will be less effective at influencing winter stream temperatures than for summer temperatures. In order to effectively manage winter stream temperatures, management activities may need to focus on catchment-scale decisions that impact snow dynamics and hillslope runoff processes. One tentative inference drawn from this study that would require further research is that forest harvesting treatments that reduce canopy closure more than observed in this study may result in increased frequency and duration of transient snow cover (Hudson, 2001) with the potential to reduce winter stream temperature.

Although our study was conducted in the Pacific Northwest of North America, the findings may have broader geographic importance for understanding winter stream temperature dynamics since rain-on-snow events occur in many temperate regions, including New Zealand (Moore and Owens, 1984) and Europe (Garvelmann et al., 2013). Furthermore, widespread shifts in hydrologic regimes from snow-dominated to rain-dominated and mixed regimes (Barnett et al., 2005; Regonda et al., 2005; Knowles et al., 2006) may result in more stream systems experiencing reduced surface ice cover, higher winter flows and increased frequency of rain-on-snow events. These hydrologic regime shifts may result in winter thermal regimes being dominated by advective fluxes associated with runoff for catchments that previously did not experience high winter runoff.

\section{Conclusions}

Advective fluxes associated with runoff processes are critical controls on winter stream temperature in the rain-onsnow zone, and the presence of transient snow cover has a detectable cooling influence on winter stream temperature. Representing these processes when predicting stream temperature response in the rain-on-snow zone to future climate change is critical. Potential climate-change-induced stream temperature increases from both warmer rain and associated advective fluxes, as well as a reduction in snow cover and associated cooling effect, could have considerable impacts on aquatic ecosystems.

Lateral runoff temperatures exhibited substantial variability in time and space, and efforts should be made to understand the controls on this variability for developing processbased models to predict winter stream temperature. Future research should address how different forest harvesting approaches, beyond the partial retention approach looked at here, may alter the transient snow dynamics and the implications that may have for winter stream temperatures. In addition, understanding how the importance of lateral advection changes when scaling from small headwater catchments to larger catchments would be valuable in predicting winter stream temperature at different scales. Future research should also attempt to rigorously link sub-lethal winter stream temperature responses to climate and land cover changes with their impacts on aquatic ecosystems.

\section{Appendix A}

\section{Monte Carlo test of significance}

The Monte Carlo approach involved the generation of stochastic realizations of snow cover for the 13 winters of historic stream temperature data. The air temperature, precipitation and stream temperature data were kept fixed in order to respect their correlation structures. To account for the inherent autocorrelation of snow cover presence/absence, we developed a transition probability matrix that included the probability of day $i$ having snow depending on whether there was snow cover on day $i-1$. These probabilities were computed from the modelled snow cover for the 13 winters of stream temperature data.

Five thousand realizations of snow cover were generated for the historic study period using the transition probability matrix. Days with rain and air temperatures between 0 and $5^{\circ} \mathrm{C}$ were extracted to calculate mean stream temperature for rain-on-snow and rain-on-bare-ground conditions. The mean difference in stream temperature between rain-on-snow and rain-on-bare-ground days for the 5000 realizations had a mean of $0.1^{\circ} \mathrm{C}$ and a standard deviation of $0.3^{\circ} \mathrm{C}$. The mean stream temperature difference between the observed rain-onsnow and rain-on-bare-ground days was $-1.4{ }^{\circ} \mathrm{C}$. The observed mean difference fell outside the range of differences based on 5000 realizations, suggesting a $p$ value of $<0.001$.

Acknowledgements. This study is part of a broader project funded by a Natural Sciences and Engineering Research Council (NSERC) Discovery Grant to R. D. Moore. J. A. Leach was supported by a Canadian Graduate Scholarship (NSERC), Donald Gray Scholarship in Canadian Hydrology (Canadian Geophysical Union), and Dillon Consulting Scholarship (Canadian Water Resources Association). Field assistance was provided by Eli Heyman, Spencer Pasieka, Saskia Hövelmann, Derek van der Kamp, Joel Trubilowicz, Justin Knudson, and Kaitlin Kazmierowski. Russell Smith provided assistance with the fabrication and installation of the snow lysimeters. Eric Leinberger created Fig. 1. The staff at the Malcolm Knapp Research Forest is greatly appreciated for logistic help. Rhett Jackson and two anonymous reviewers provided feedback that greatly improved the clarity of the manuscript.

Edited by: M. Hrachowitz 


\section{References}

Arismendi, I., Johnson, S. L., Dunham, J. B., Haggerty, R., and Hockman-Wert, D.: The paradox of cooling streams in a warming world: regional climate trends do not parallel variable local trends in stream temperature in the Pacific continental United States, Geophys. Res. Lett., 39, L10401, doi:10.1029/2012GL051448, 2012.

Arismendi, I., Johnson, S. L., Dunham, J. B., and Haggerty, R.: Descriptors of natural thermal regimes in streams and their responsiveness to change in the Pacific Northwest of North America, Freshwater Biol., 58, 880-894, 2013.

Barnett, T. P., Adam, J. C., and Lettenmaier, D. P.: Potential impacts of a warming climate on water availability in snow-dominated regions, Nature, 438, 303-309, 2005.

Bartholow, J.: Recent water temperature trends in the Lower Klamath River, California, N. Am. J. Fish. Manage., 25, 152-162, 2005.

Battin, J., Wiley, M. J., Ruckelshaus, M. H., Palmer, R. N., Korb, E., Bartz, K. K., and Imaki, H.: Projected impacts of future climate change on salmon habitat restoration actions in a Puget Sound River, P. Natl. Acad. Sci. USA, 104, 6720-6725, 2007.

Baxter, C., Hauer, F. R., and Woessner, W. W.: Measuring groundwater-stream water exchange: new techniques for installing minipiezometers and estimating hydraulic conductivity, T. Am. Fish. Soc., 132, 493-502, 2003.

Baxter, C., Fausch, K. D., and Saunders, W. C.: Tangled webs: reciprocal flows of invertebrate prey link streams and riparian zones, Freshwater Biol., 50, 201-220, 2005.

Benyahya, L., Caissie, D., Satish, M. G., and El-Jabi, N.: Longwave radiation and heat flux estimates within a small tributary in Catamaran Brook (New Brunswick, Canada), Hydrol. Process., 26, 475-484, 2012.

Berris, S. N. and Harr, R. D.: Comparative snow accumulation and melt during rainfall in forested and clear-cut plots in the western Cascades of Oregon, Water Resour. Res., 23, 135-142, 1987.

Beschta, R. L., Bilby, R. E., Brown, G., Holtby, L. B., and Hofstra, T. D.: Stream temperature and aquatic habitat: fisheries and forestry interactions, in: Streamside Management: Forestry and Fishery Interactions, no. 57, edited by: Salo, E. O. and Cundy, T. W., University of Washington, Institute of Forest Resources, Seattle, Washington, 191-232, 1987.

Bevington, P. R. and Robinson, K. D.: Data Reduction and Error Analysis for the Physical Sciences, 3rd Edn., McGraw-Hill, Boston, 2003.

Birkinshaw, S. J., and Webb, B.: Flow pathways in the Slapton Wood catchment using temperature as a tracer, J. Hydrol., 383, 269-279, 2010.

Black, T. A., Chen, J. M., Lee, X., and Sagar, R. M.: Characteristics of shortwave and longwave irradiances under a Douglas-fir forest stand, Can. J. Forest Res., 21, 1020-1028, 1991.

Brown, L. E., Hannah, D. M., and Milner, A. M.: Vulnerability of alpine stream biodiversity to shrinking glaciers and snowpacks, Global Change Biol., 13, 958-966, 2007.

Brown, R. S., Hubert, W. A., and Daly, S. F.: A primer on winter, ice, and fish: what fisheries biologists should know about winter ice processes and stream-dwelling fish, Fisheries, 36, 8-26, 2011.
Bulliner, E. and Hubbart, J. A.: An improved hemispherical photography model for stream surface shortwave radiation estimations in a central US hardwood forest, Hydrol. Process., 27, 38853895, 2013.

Cheng, J. D.: Subsurface stormflows in the highly permeable forested watersheds of southwestern British Columbia, J. Contam. Hydrol., 3, 171-191, 1988.

Danehy, R. J., Colson, C. G., and Duke, S. D.: Winter longitudinal thermal regime in four mountain streams, Northwest Sci., 84, 151-158, 2010.

De Groot, J. D., Hinch, S. G., and Richardson, J. S.: Effects of logging second-growth forests on headwater populations of coastal cutthroat trout: a 6-year, multistream, before-and-after field experiment, T. Am. Fish. Soc., 136, 211-226, 2007.

Donnelly-Makowecki, L. M. and Moore, R. D.: Hierarchical testing of three rainfall-runoff models in small forested catchments, J. Hydrol., 219, 136-152, 1999.

Durance, I. and Ormerod, S. J.: Climate change effects on upland stream macroinvertebrates over a 25 -year period, Global Change Biol., 13, 942-957, 2007.

Durance, I. and Ormerod, S. J.: Trends in water quality and discharge confound long-term warming effects on river macroinvertebrates, Freshwater Biol., 54, 388-405, 2009.

Ebersole, J., Wigington Jr., P., Baker, J., Cairns, M., Church, M., Hansen, B., Miller, B., LaVigne, H., Compton, J., and Leibowitz, S.: Juvenile coho salmon growth and survival across stream network seasonal habitats, T. Am. Fish. Soc., 135, 16811697, 2006.

Feller, M. C. and Kimmins, J. P.: Chemical characteristics of small streams near Haney in southwestern British Columbia, Water Resour. Res., 15, 247-258, 1979.

Ficklin, D. L., Luo, Y., Stewart, I. T., and Maurer, E. P.: Development and application of a hydroclimatological stream temperature model within the Soil and Water Assessment Tool, Water Resour. Res., 48, W01511, doi:10.1029/2011WR011256, 2012.

Floyd, W. and Weiler, M.: Measuring snow accumulation and ablation dynamics during rain-on-snow events: innovative measurement techniques, Hydrol. Process., 22, 4805-4812, 2008.

Frazer, G. W., Canham, C. D., and Lertzman, K. P.: Gap Light Analyser (GLA), Version 2.0: Imaging Software to Extract Canopy Structure and Light Transmission Indices from True-Colour Fisheye Photographs, User's Manual and Program Documentation, Simon Fraser University, Burnady, British Columbia, 1999.

Freeze, R. A. and Cherry, J. A.: Groundwater, Prentice-Hall, Englewoods, 1979.

Friberg, N., Bergfur, J. J. R., and Sandin, L.: Changing Northern catchments: is altered hydrology, temperature or both going to shape future stream communities and ecosystem processes?, Hydrol. Process., 27, 734-740, 2013.

Gaffield, S., Potter, K., and Wang, L.: Predicting the summer temperature of small streams in southwestern Wisconsin, J. Am. Water Resour. Ass., 41, 25-36, 2005.

Garvelmann, J., Pohl, S., and Weiler, M.: From observation to the quantification of snow processes with a time-lapse camera network, Hydrol. Earth Syst. Sci., 17, 1415-1429, doi:10.5194/hess-17-1415-2013, 2013. 
Gomi, T., Moore, R. D., and Dhakal, A. S.: Headwater stream temperature response to clear-cut harvesting with different riparian treatments, coastal British Columbia, Canada, Water Resour. Res., 42, W08437, doi:10.1029/2005WR004162, 2006.

Gravelle, J. A. and Link, T. E.: Influence of timber harvesting on water temperatures in a northern Idaho watershed, Forest Sci., 53, 189-205, 2007.

Guenther, S. M.: Impacts of Partial-Retention Harvesting With no Buffer on the Thermal Regime of a Headwater Stream and its Riparian Zone, Master's thesis, University of British Columbia, Vancouver, British Columbia, Canada, 2007.

Guenther, S. M., Moore, R. D., and Gomi, T.: Riparian microclimate and evaporation from a coastal headwater stream and their response to partial-retention forest harvesting, Agr. Forest Meteorol., 164, 1-9, 2012.

Guenther, S. M., Gomi, T., and Moore, R. D.: Stream and bed temperature variability in a coastal headwater catchment: influences of surface-subsurface interactions and partial-retention forest harvesting, Hydrol. Process., 28, 1238-1249, 2014.

Hannah, D. M., Malcolm, I. A., Soulsby, C., and Youngson, A. F.: Heat exchanges and temperatures within a salmon spawning stream in the Cairngorms, Scotland: seasonal and sub-seasonal dynamics, River Res. Appl., 20, 635-652, 2004.

Hannah, D. M., Malcolm, I. A., Soulsby, C., and Youngson, A. F.: A comparison of forest and moorland stream microclimate, heat exchanges and thermal dynamics, Hydrol. Process., 22, 919-940, 2008.

Haught, D. R. W. and van Meerveld, H. J.: Spatial variation in transient water table responses: differences between an upper and lower hillslope zone, Hydrol. Process., 25, 3866-3877, 2011.

Hebert, C., Caissie, D., Satish, M. G., and El-Jabi, N.: Study of stream temperature dynamics and corresponding heat fluxes within Miramichi River catchments (New Brunswick, Canada), Hydrol. Process., 25, 2439-2455, 2011.

Hester, E., Doyle, M., and Poole, G.: The influence of in-stream structures on summer water temperatures via induced hyporheic exchange, Limnol. Oceanogr., 54, 355-367, 2009.

Hetherington, E. D.: Investigation of orographic rainfall in south coastal mountains of British Columbia, Ph.D. thesis, University of British Columbia, Vancouver, British Columbia, Canada, 1976.

Holtby, L. B.: Effects of logging on stream temperatures in Carnation Creek British Columbia, and associated impacts on the coho salmon (Oncorhynchus kisutch), Can. J. Fish. Aquat. Sci., 45, 502-515, 1988 .

Hudson, R. O.: Roberts Creek Study Forest: Preliminary Effects of Partial Harvesting on Peak Streamflow in Two S6 Creeks, Technical Report, B.C. Forest Service, Vancouver Forest Region, Forest Research Extension Note EN-007 (March 2001), Nanaimo, British Columbia, Canada, 2001.

Hutchinson, D. G. and Moore, R. D.: Throughflow variability on a forested hillslope underlain by compacted glacial till, Hydrol. Process., 14, 1751-1766, 2000.

Huusko, A., Greenberg, L., Stickler, M., Linnansaari, T., Nykänen, M., Vehanen, T., Koljonen, S., Louhi, P., and Alfredsen, K.: Life in the ice lane: the winter ecology of stream salmonids, River Res. Appl., 23, 469-491, 2007.
Hvorslev, M. J.: Time Lag and Soil Permeability in Ground-Water Observations, Technical Report, Waterways Experimental Station, Corps of Engineers, US Army, Vicksburg, Mississippi, 1951.

Imholt, C., Soulsby, C., Malcolm, I. A., and Gibbins, N. C.: Influence of contrasting riparian forest cover on stream temperature dynamics in salmonid spawning and nursery streams, Ecohydrology, 6, 380-392, 2013.

Janisch, J., Wondzell, S. M., and Ehinger, W. J.: Headwater stream temperature: Interpreting response after logging, with and without riparian buffers, Washington, USA, Forest Ecol. Manage., 270, 302-313, 2012.

Jencso, K. G., McGlynn, B. L., Gooseff, M. N., Wondzell, S. M., Bencala, K. E., and Marshall, L. A.: Hydrologic connectivity between landscapes and streams: transferring reach-and plot-scale understanding to the catchment scale, Water Resour. Res., 45, W04428, doi:10.1029/2008WR007225, 2009.

Johnson, S. L.: Factors influencing stream temperatures in small streams: substrate effects and a shading experiment, Can. J. Fish. Aquat. Sci., 61, 913-923, 2004.

Johnson, S. L. and Jones, J. A.: Stream temperature responses to forest harvest and debris flows in western Cascades, Oregon, Can. J. Fish. Aquat. Sci., 57, 30-39, 2000.

Jones, J. A.: Hydrologic processes and peak discharge response to forest removal, regrowth, and roads in 10 small experimental basins, western Cascades, Oregon, Water Resour. Res., 36, 2621-2642, 2000.

Knowles, N., Dettinger, M. D., and Cayan, D. R.: Trends in snowfall versus rainfall in the western United States, J. Climate, 19, 45454559, 2006.

Kobayashi, D., Ishii, Y., and Kodama, Y.: Stream temperature, specific conductance and runoff process in mountain watersheds, Hydrol. Process., 13, 865-876, 1999.

Langan, S., Johnston, L., Donaghy, M., Youngson, A., Hay, D., and Soulsby, C.: Variation in river water temperatures in an upland stream over a 30-year period, Sci. Total Environ., 265, 195-207, 2001.

Lapham, W. W.: Use of Temperature Profiles Beneath Streams to Determine Rates of Vertical Ground-Water Flow and Vertical Hydraulic Conductivity, Technical Report, USGS Water-Supply Paper 2337, US Government Printing Office, Washington, D.C., 35 pp., 1989.

Leach, J. A.: Stream temperature dynamics following riparian wildfire: effects of stream-subsurface interactions and standing dead trees, Master's thesis, University of British Columbia, Vancouver, British Columbia, Canada, 2008

Leach, J. A. and Moore, R. D.: Above-stream microclimate and stream surface energy exchanges in a wildfire-disturbed riparian zone, Hydrol. Process., 24, 2369-2381, 2010.

Leach, J. A. and Moore, R. D.: Stream temperature dynamics in two hydrogeomorphically distinct reaches, Hydrol. Process., 25 , 679-690, 2011.

Leach, J. A., Moore, R. D., Hinch, S. G., and Gomi, T.: Estimation of forest harvesting-induced stream temperature changes and bioenergetic consequences for cutthroat trout in a coastal stream in British Columbia, Canada, Aquat. Sci., 74, 427-441, 2012.

MacDonald, R. J., Boon, S., Byrne, J. M., and Silins, U.: A comparison of surface and subsurface controls on summer temperature in a headwater stream, Hydrol. Process., 28, 2338-2347, 2014. 
Malard, F., Mangin, A., Uehlinger, U., and Ward, J.: Thermal heterogeneity in the hyporheic zone of a glacial floodplain, Can. J. Fish. Aquat. Sci., 58, 1319-1335, 2001.

Marks, D., Kimball, J., Tingey, D., and Link, T.: The sensitivity of snowmelt processes to climate conditions and forest cover during rain-on-snow: a case study of the 1996 Pacific Northwest flood, Hydrol. Process., 12, 1569-1587, 1998.

Moore, R. D.: Application of a conceptual streamflow model in a glacierized drainage basin, J. Hydrol., 150, 151-168, 1993.

Moore, R. D.: Introduction to salt dilution gauging for streamflow measurement Part II: Constant-rate injection, Streamline Watershed Manage. Bull., 8, 11-15, 2004.

Moore, R. D. and Owens, I. F.: A conceptual runoff model for a mountainous rain-on-snow environment, Craigieburn Range, New Zealand, J. Hydrol., 23, 84-99, 1984.

Moore, R. D., Sutherland, P., Gomi, T., and Dhakal, A.: Thermal regime of a headwater stream within a clear-cut, coastal British Columbia, Canada, Hydrol. Process., 19, 2591-2608, 2005.

Mote, P. W. and Salathe, E. P.: Future climate in the Pacific Northwest, Climatic Change, 102, 29-50, 2010.

Neilson, B. T., Stevens, D. K., Chapra, S. C., and Bandaradoga, C.: Data collection methodology for dynamic temperature model testing and corroboration, Hydrol. Process., 23, 2902-2914, 2009.

Oke, T.: Boundary Layer Climates, 2nd Edn., Halsted Press, London, UK, 1987.

Pomeroy, J. W., Marks, D., Link, T., Ellis, C., Hardy, J., Rowlands, A., and Granger, R.: The impact of coniferous forest temperatures on incoming longwave radiation to melting snow, Hydrol. Process., 23, 2513-2525, 2009.

Regonda, S. K., Rajagopalan, B., Clark, M., and Pitlick, J.: Seasonal cycle shifts in hydroclimatology over the western United States, J. Climate, 18, 372-384, 2005.

Richardson, J. S., Naiman, R. J., Swanson, F. J., and Hibbs, D. E.: Riparian communities associated with Pacific Northwest headwater streams: assemblages, processes, and uniqueness, J. Am. Water Resour. Assoc., 41, 935-947, 2005.

Rodenhuis, D. R., Bennett, K. E., Werner, A. T., Murdock, T. Q., and Bronaugh, D.: Hydro-climatology and future climate impacts in British Columbia, Pacific Climate Impacts Consortium, University of Victoria, Victoria, British Columbia, 2007.

Scordo, E. B. and Moore, R. D.: Transient storage processes in a steep headwater stream, Hydrol. Process., 23, 2671-2685, 2009.

Shanley, J. and Peters, N.: Preliminary observations of streamflow generation during storms in a forested Piedmont watershed using temperature as a tracer, J. Contam. Hydrol., 3, 349-365, 1988.

Shuter, B. J., Finstad, A. G., Helland, I. P., Zweimüller, I., and Hölker, F.: The role of winter phenology in shaping the ecology of freshwater fish and their sensitivities to climate change, Aquat. Sci., 74, 637-657, 2012.

Sinokrot, B. and Stefan, H.: Stream temperature dynamics: measurements and modeling, Water Resour. Res., 29, 2299-2312, 1993.
Smith, R.: Space-Time Dynamics of Runoff Generation in a Snowmelt-Dominated Montane Catchment, Ph.D. thesis, University of British Columbia, Vancouver, British Columbia, Canada, 2011.

St-Hilaire, A., Morin, G., El-Jabi, N., and Caissie, D.: Water temperature modelling in a small forested stream: implications of forest canopy and soil temperatures, Can. J. Civil Eng., 27, 10951108, 2000.

Storck, P., Lettenmaier, D. P., and Bolton, S. M.: Measurement of snow interception and canopy effects on snow accumulation and melt in a mountainous maritime climate, Oregon, United States, Water Resour. Res., 38, 1223, doi:10.1029/2002WR001281, 2002.

Story, A., Moore, R. D., and Macdonald, J. S.: Stream temperatures in two shaded reaches below cutblocks and logging roads: downstream cooling linked to subsurface hydrology, Can. J. Forest Res., 33, 1383-1396, 2003.

Subehi, L., Fukushima, T., Onda, Y., Mizugaki, S., Gomi, T., Kosugi, K., Hiramatsu, S., Kitahara, H., Kuraji, K., and Terajima, T.: Analysis of stream water temperature changes during rainfall events in forested watersheds, Limnology, 11, 115-124, 2010.

Thompson, J. C. and Moore, R. D.: Relations between topography and water table depth in a shallow forest soil, Hydrol. Process., 10, 1513-1525, 1996.

Utting, M. G.: The Generation of Stormflow on a Glaciated Hillslope in Coastal British Columbia, Master's thesis, University of British Columbia, Vancouver, Canada, 1979.

Ward, A. S., Gooseff, M. N., Voltz, T. J., Fitzgerald, M., Singha, K., and Zarnetske, J. P.: How does rapidly changing discharge during storm events affect transient storage and channel water balance in a headwater mountain stream?, Water Resour. Res., 49, 5473 5486, doi:10.1002/wrcr.20434, 2013.

Watz, J., Bergman, E., Piccolo, J. J., and Greenberg, L.: Effects of ice cover on the diel behaviour and ventilation rate of juvenile brown trout, Freshwater Biol., 58, 2325-2332, doi:10.1111/fwb.12212, 2013.

Webb, B. W. and Crisp, D. T.: Afforestation and stream temperature in a temperate maritime environment, Hydrol. Process., 20, 5166,2006

Webb, B. W. and Zhang, Y.: Spatial and seasonal variability in the components of the river heat budget, Hydrol. Process., 11, 79$101,1997$.

Webb, B. W. and Zhang, Y.: Water temperatures and heat budgets in Dorset chalk water courses, Hydrol. Process., 13, 309-321, 1999.

Webb, B. W., Hannah, D. M., Moore, R. D., Brown, L. E., and Nobilis, F.: Recent advances in stream and river temperature research, Hydrol. Process., 22, 902-918, 2008.

Wehrly, K. E., Wiley, M. J., and Seelbach, P. W.: Classifying regional variation in thermal regime based on stream fish community patterns, T. Am. Fish. Soc., 132, 18-38, 2003.

Wehrly, K. E., Wang, L., and Mitro, M.: Field-based estimates of thermal tolerance limits for trout: incorporating exposure time and temperature fluctuation, T. Am. Fish. Soc., 136, 365-374, 2007. 